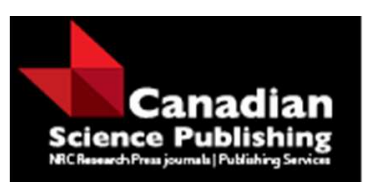

Canadian Journal of Physics

Revue canadienne de physique

\title{
Experimental and quantum chemical studies on the structure and vibrational spectra of Cearoin (a neoflavonoid)
}

\begin{tabular}{|r|l|}
\hline Journal: & Canadian Journal of Physics \\
\hline Manuscript ID & Cjp-2016-0847.R2 \\
\hline Danuscript Type: & Article \\
\hline Complete List of Authors: & $\begin{array}{l}\text { Rao, Shweta; University of Lucknow, Department of Physics } \\
\text { Khan, Eram; University of Lucknow, Depratment of Physics } \\
\text { Tandon, Poonam; University of Lucknow, Physics } \\
\text { Bharti, Purnima; University of Lucknow, Department of Physics } \\
\text { Kumar, Padam; Central Drug Research Institute } \\
\text { Maurya, Rakesh; Central Drug Research Institute }\end{array}$ \\
\hline Keyword: & cearoin, conformational studies, FT-IR, FT-Raman, UV-Visible \\
\hline Please Select from this Special & N/A \\
Issues list if applicable: & 24-Mar-2017 \\
\hline \multicolumn{2}{|l}{} \\
\hline
\end{tabular}




\title{
Experimental and quantum chemical studies on the structure and vibrational spectra of Cearoin (a neoflavonoid)
}

\author{
$\underline{\text { Shweta }^{\mathrm{a}}}$, Eram Khan ${ }^{\mathrm{a}}$, Poonam Tandon ${ }^{* a}$, PurnimaBharti $^{\mathrm{a}}$, PadamKumar $^{\mathrm{b}}$, RakeshMaurya $^{\mathrm{b}}$ \\ ${ }^{a}$ Department of Physics, University of Lucknow, Lucknow-226007, India. \\ ${ }^{\mathrm{b}}$ Medicinal and Process Chemistry Division, Central Drug Research Institute (CDRI), Lucknow 226031, India.
}

\section{Abstract}

In the present investigation, the natural product Cearoin is studied by both experimental and theoretical methods. It is classified as a family of neoflavonoid and is widely used as local anti-inflammatory, antibiotic and antiallergic substance. To obtain the detailed information about the discussed molecule a number of experiments has been performed by various techniques including IR, Raman and UV-Visible spectroscopy. Quantum chemical calculations were also performed for a clear interpretation and analysis of the results. HOMO-LUMO energy band gap gives a valuable understanding of the reactivity and some of the structural and physical properties of the theme molecule. Molecular electrostatic potential surface (MEPS), global and local reactivity descriptors are used to study the chemical reactivity of the molecule.Natural Bond Orbital (NBO) analysis is followed to figure out the stability of the molecule arising from hyperconjugative interactions and charge delocalization. As cearoin is utilized as an antibiotic material, molecular docking simulations has also been done on bacterial proteins in order to investigate the ligand-protein interaction.

* Corresponding author. Tel.: +91522 2782653; fax: +91522 2740840.

E-mail addresses: poonam_tandon@yahoo.co.uk, poonam_tandon@hotmail.com (P. Tandon).

Keywords: Cearoin, Conformational studies, FT-IR, FT-Raman, UV-Visible.

\section{Introduction}


31 Cearoin (2,5-dihydroxy-4-methoxyphenyl)-phenylmethanone) is a natural compound, that

32 fall into the category of neoflavonoids (a class of polyphenolic compounds). Recently for the

33 first time Maurya et al.[1-2] extracted it from dalbergia sissoo, which is a large deciduous

34 perennial tree, belonging to the legume family (Fabaceae), and sub family (Faboideae) [2].

35 Structural information of cearoin $(\mathrm{CRN})$ was obtained from NMR (carbon and proton), mass

36 spectrometry and vibrational spectroscopy and compared with already reported data [3]. CRN

37 has recently gain much attention of the medicinal research as it is very useful in the treatment

38 of problems such as Osteoporosis, allergy, inflammation, bacterial and microbial infections

39 [2-10]. It is also proved by various clinical and epidemiological studies that CRN can have

40 significant influence in the inhibition of various diseases, at primary as well as secondary

41 level [4,11-13].To further aid that research, the present investigation is on CRN isolated from

42 bark of dalbergia sissoo.

43 Spectroscopic and quantum chemical techniques are significant procedures to understand

44 the molecular structure, conformational analysis, composition, dynamical behaviour and

45 intramolecular interactions of complex molecules. The substantial characterization of CRN is

46 experimentally done by a variety of methods comprising vibrational spectroscopy (IR and

47 Raman), and UV-Visible spectroscopy. Since intramolecular and charge transfer interactions

48 play a vital role in binding drug-protein complex. Hence, spectroscopic studies have been

49 performed to analyse the intramolecular interactions. The molecular structure, energies and

50 vibrational frequencies of the optimized geometries of CRN were computed using the density

51 functional theory (DFT) method. Potential energy distribution (PED) is used as a base for the

52 understanding of the energy distribution.Vibrational assignment of the normal modes was

53 done on the basis of PED. Molecular electrostatic potential surface (MEPS) of CRN has been

54 interpreted for determining the structure-activity relationship, which gives valuable

55 information for the quality control of medicines and drug-receptor interactions. Natural bond 
56 orbital (NBO) analysis has been done to investigate stability of CRN arising from

57 intramolecular charge transfer interactions. Molecular docking studies were performed for 58 understanding the biological activity of $\mathrm{CRN}$ with the protein.

\section{Experimental details}

\subsection{Infrared spectroscopy}

Infrared spectra was recorded on a Bruker TENSOR 27 FT-IR spectrometer with a spectral resolution of $4 \mathrm{~cm}^{-1}$ in the region $400-3700 \mathrm{~cm}^{-1} . \mathrm{KBr}$ pellets of solid samples were prepared from mixtures of the sample and $\mathrm{KBr}$ in 1:200 ratio using a hydraulic press.

\subsection{FT-Raman spectroscopy}

The FT-Raman spectrum of the CRN was recorded on a Bruker IFS 55 EQUINOX with Raman setup which uses a $1064 \mathrm{~nm} \mathrm{Nd-YAG} \mathrm{laser} \mathrm{line} \mathrm{as} \mathrm{the} \mathrm{excitation} \mathrm{line} \mathrm{for} \mathrm{recording}$ the Raman spectra in the region $100-3700 \mathrm{~cm}^{-1}$. The samples are measured in the hemispheric bore of an aluminium sample holder. The spectral resolution of this instrument was also $4 \mathrm{~cm}^{-1}$. Typical spectra are acquired with 512 scans and a laser power of $500 \mathrm{~mW}$ at the sample location.

\subsection{UV-visible spectroscopy}

The UV-visible absorption spectrum of CRN was recorded in the range 300-500 nm using a Varian-Cary 50 Bio, UV-visible Spectrophotometer equipped with a $10 \mathrm{~mm}$ quartz cell. The UV spectrum is taken from a $1 \times 10^{-5} \mathrm{M}$ solution of CRN dissolved in DMSO solvent at $30^{\circ} \mathrm{C}$.

\section{Computational details}

The electronic structure and optimized geometry of CRN were computed by the DFT method using the Gaussian 09 program [14] package employing 6-311++G(d,p) basis

81 set and Becke's three parameter (local, nonlocal, Hartree-Fock) hybrid exchange 
82 functionals with Lee-Yang-Parr correlation functional (B3LYP)[15-18]. The optimized structures were compared using Chem3D software by superimposing them and minimizing the root square distance between selected atoms[19].Electronic transitions of the molecule were calculated using time-dependent density functional theory (TD-DFT) for both gaseous as well as for solvent phase [20,21]. The solvent effects were taken into account by means of IEF-PCM solvation model[2223].Visualization and confirmation of calculated data were done by using the ChemCraft[24] and GaussView [25] program.Gar2ped program was used for the vibrational assignment of the modes[26]. For this purpose a complete set of 84 internal coordinates was defined using Pulay's recommendations[27-28]. To account for the antibioticactivity of the CRN, molecular docking (ligand-protein) simulations have been performed using AutoDock1.5.4 software [29]. The active sites were examined for detailed interactions in Discovery Studio Visualizer 4.5 software[30].

\section{Results and discussion}

\subsection{Conformational studies}

The ground state optimized energy of CRN was calculated as -841.8282644 Hartree. In order to reveal all possible conformers and to get the most stable conformer of CRN, detailed 1D (one dimensional) potential energy scans were performed for the dihedral angles $\phi 1(\mathrm{C} 12-\mathrm{C} 6-\mathrm{C} 5-\mathrm{O} 3), \quad \phi 2(\mathrm{C} 8-\mathrm{C} 4-\mathrm{C} 5-\mathrm{O} 3), \quad \phi 3(\mathrm{H} 25-\mathrm{O} 2-\mathrm{C} 7-\mathrm{C} 10)$, $\phi 4(\mathrm{H} 30-\mathrm{O} 29-\mathrm{C} 11-\mathrm{C} 8), \quad \phi 5(\mathrm{C} 17-\mathrm{O} 1-\mathrm{C} 9-\mathrm{C} 10) \quad$ and $\quad \phi 6(\mathrm{H} 26-\mathrm{C} 17-\mathrm{O} 1-\mathrm{C} 9) \quad$ using B3LYP/6-311++G(d,p) basis set. Around these bonds, the variation of torsion angles was carried out at a step of $10^{\circ}$ in the range of $0-360^{\circ}$ rotation. The potential energy scans of these bonds, obtained by changing the potential energy as a function of dihedral angles are given in Fig.1. Conformers are considered on the basis of global minima. In total four conformers were obtained and the optimized structures of all the 
107 conformers along with their relative energies are presented in Fig. S1. Amongst these,

108 the conformerI (CRN I) and conformer II (CRN II) have minimum energy of $109-841.828264$ and -841.824109 Hartree, respectively compared to all the other 110 conformers, which implies that CRN I is the most stable conformer. The optimized 111 energies and the energy difference of all the conformers with respect to the most stable 112 conformer are given in Table S1.

\subsection{Geometry optimizations and energies}

The geometrically optimized structures of CRN I and CRN II in addition to the atom number scheme are shown in Fig. 2. A comparison of the structural parameters (bond lengths, bond angles and dihedral angles) of CRN I and CRN II obtained by geometry optimization by DFT methods are presented in Table S2.The optimized structure of both conformers CRN I and CRN II was compared by nearly superimposing them using a least squares algorithm that minimizes the distances of the corresponding non hydrogen atoms as shown in Fig.S2. It is clear from Fig.S2 that both the conformers nearly overlapped but, the methoxy group, hydroxyl group and ring R2 shows some differences; this is due to the difference in their direction of orientation. The bond lengths of CRN I and CRN II are almost same. The bond angles C5-C4-C7,C2-C7-C4,O1-C9-C11, O1-C9-C10 and O1-C9-C11 showed a difference of $1.3741^{\circ}, 6.5146^{\circ},-5.5912^{\circ},-8.2831^{\circ}$, and $9.3485^{\circ}$. The other bond angles in both conformers are almost the same and do not show significant differences. The dihedral angles O3-C5-C6-C13, C8-C4-C5-O3, H25-O2-C7-C10, C8-C11-H29-H30, C9-O1-C17-H26 and C17-O1-C9-C10 showed a difference of $10.5266^{\circ},-11.7135^{\circ}, 176.6143^{\circ},-6.4727^{\circ}$ and $-129.4928^{\circ}$ between both conformers. The two rings R1 and R2 are essentially planar in both the conformers. 
132

133

134

135

136

137

138

139

140

141

142

143

\subsection{Vibrational Spectra and Assignments}

$\mathrm{CRN}$ has 30 atoms; hence it gives $84(3 \mathrm{~N}-6)$ normal modes of vibrations. The vibrational spectrum is mainly determined by the modes of the free molecule observed at higher wavenumbers, together with the lattice (translational and vibrational) modes in the low wavenumber region.

DFT calculations yield Raman scattering amplitudes which cannot be taken directly to be the Raman intensities. The Raman scattering cross section, $\partial \sigma_{\mathrm{j}} / \partial \Omega$, which is proportional to Raman intensity may be calculated from the Raman scattering amplitude and predicted wavenumbers for each normal mode using the relationship [31,32]

$$
\frac{\partial \sigma_{\mathrm{j}}}{\partial \Omega}=\left(\frac{2^{4} \pi^{4}}{45}\right)\left(\frac{\left(v_{0}-v_{j}\right)^{4}}{1-\exp \left[\frac{-h c v_{j}}{k T}\right]}\right)\left(\frac{h}{8 \pi^{2} c v_{j}}\right) S_{j}
$$

Where $S_{j}$ and $v_{j}$ are the scattering activities and the predicted wavenumbers, respectively of the $j^{\text {th }}$ normal mode, $\partial \Omega$ is the solid angle, $v_{0}$ is the wavenumber of the Raman excitation line and $h, c$ and $k$ are universal constants. The calculated Raman and IR intensities were used to convolute each predicted vibrational mode with a Lorentzian line shape $\left(\mathrm{FWHM}=8 \mathrm{~cm}^{-1}\right)$ to produce simulated spectra. Assignments have been made on the basis of relative intensities, energies, line shape and PED. All the vibrational bands have been assigned adequately. The detailed assignment of the wavenumbers of the vibrational modes together with their PED is given in Table 1.

\subsection{Vibrational wavenumber}

The comparison of the wavenumbers calculated at B3LYP level with the observed spectra reveals an overestimation of the wavenumbers of the vibrational modes. This is due to the anharmonicity present in a real system which was not taken into consideration. The 
155 vibrational wavenumbers were scaled down by the wavenumber linear scaling procedure 156 (WLS) $\left[v_{\mathrm{obs}}=\left(1.0087-0.000016^{*} v_{\mathrm{cal}}\right) v_{\mathrm{cal}}\right][33]$, as the wavenumbers obtained from the DFT 157 calculations are higher than the observed wavenumbers. The vibrational wavenumbers 158 calculated with appropriate functional are often found in good agreement with the observed wavenumbers when the calculated wavenumbers are uniformly scaled with only one scaling factor [34,35]. All the calculated vibrational wavenumbers for both the conformers reported in this study are the scaled values and were comparatively the same. The evaluation of observed and calculated (scaled) IR and Raman spectra of CRN I and CRN II are shown in Fig. 3 and Fig.4, respectively. There are two significant rings in the CRN and hence we discuss the assignment of these two rings individually.

\subsubsection{Ring R1 Vibrations}

167 The R1 ring vibrations are mainly of two types, one is predominantly $\mathrm{C}-\mathrm{H}$ stretching 168 vibrations and another is $\mathrm{C}-\mathrm{C}$ stretching vibration. The $\mathrm{CH}$ stretching mode of the ring is calculated at $3036 / 3032 \mathrm{~cm}^{-1}$ in CRN I/II and assigned to the IR/Raman peak at 3020/3025 $\mathrm{cm}^{-1}$. The ring CC stretching band is calculated at $1630 / 1625 \mathrm{~cm}^{-1}$ in CRN I/II with medium intensity and observed at $1638 / 1634 \mathrm{~cm}^{-1}$ is IR/Raman spectra. The $\mathrm{C}-\mathrm{H}$ in-plane 172 deformation is observed at $1283 \mathrm{~cm}^{-1}$ in the IR spectra and matches well with the calculated wavenumber at $1286 \mathrm{~cm}^{-1}$ for both the conformers [36-37]. The torsional deformation mode of ring R1 is calculated at $1009 / 1007 \mathrm{~cm}^{-1}$ corresponding to the observed IR mode at 1011 $\mathrm{cm}^{-1}$. The peaks at the wavenumber $885 \mathrm{~cm}^{-1}$ and $906 \mathrm{~cm}^{-1}$ in both IR and Raman spectra and 176 at the wavenumber $900 / 891 \mathrm{~cm}^{-1}$ in CRNI/II are assigned to the C-H out-of-plane bending

177 vibration. Puckering mode calculated at $703 \mathrm{~cm}^{-1}$ and $709 \mathrm{~cm}^{-1}$ for CRN I and CRN II corresponds to the observed peaks at 705 and $700 \mathrm{~cm}^{-1}$ in both Raman and IR spectra. 


\subsubsection{Ring R2 Vibration}

The $\mathrm{CH}$ stretching modes are observed at $3076 / 3075 \mathrm{~cm}^{-1}$ in the IR/Raman spectra and are predicted at $3059 / 3060 \mathrm{~cm}^{-1}$ and $3053 / 3054 \mathrm{~cm}^{-1}$ for CRN I/II. The C-C stretching vibrations bond occurs at $1572 \mathrm{~cm}^{-1}$ in the IR spectrum and at $1570 \mathrm{~cm}^{-1}$ in the Raman spectrum. They are calculated at $1589 / 1578 \mathrm{~cm}^{-1}$ for CRN I/II and observed at $1587 / 1570 \mathrm{~cm}^{-1}$ in the IR/Raman. The C-H in plane deformation modes are calculated at $1171 \mathrm{~cm}^{-1}$ and $1192 \mathrm{~cm}^{-1}$ in CRN II whereas it is calculated at $1169 / 1205 \mathrm{~cm}^{-1}$ in CRN I. The CH out of plane bending mode is calculated at $999 / 1006 \mathrm{~cm}^{-1}$ in CRNI/II and assigned to the observed IR/Raman band at $1001 / 1001 \mathrm{~cm}^{-1}$, respectively.

\subsubsection{Carbonyl and methoxy group vibration mode}

Usually carboxyl group shows its characteristic bands. The carbonyl $\mathrm{C}=\mathrm{O}$ stretching vibration absorbs strongly in the region $1670-1820 \mathrm{~cm}^{-1}[38-40]$. The strong IR band observed at $1638 \mathrm{~cm}^{-1}$ and its Raman counterpart at $1634 \mathrm{~cm}^{-1}$ are assigned to the $\mathrm{C}=\mathrm{O}$ stretching mode and calculated at 1676 and $1668 \mathrm{~cm}^{-1}$ for CRN I and CRN II. Medium intense bands at 2980, 2953 and $2911 \mathrm{~cm}^{-1}$ in the Raman spectrum are assigned to $\mathrm{C}-\mathrm{H}$ stretching asymmetric and symmetric vibrations of methoxy group. The counterpart occurred at 2993, 2951 and $2910 \mathrm{~cm}^{-1}$ in the IR spectrum matches well with predicted CRNI/II value at $3008 / 3010 \mathrm{~cm}^{-1}, 2949 / 2979 \mathrm{~cm}^{-1}$ and $2892 / 2900 \mathrm{~cm}^{-1}$.

\subsubsection{OH group vibration}

The non-hydrogen bonded or free hydroxyl group absorbs strongly in the region 3600-3550 $\mathrm{cm}^{-1}$, while the hydrogen bonding lowers the wavenumbers to the region $3550-3200 \mathrm{~cm}^{-1}$ along with increase in intensity and width of IR spectrum[41]. In the FT-IR spectra the bands due to the stretching modes of $\mathrm{O} 2 \mathrm{H}$ and $\mathrm{O} 29 \mathrm{H}$ group are assigned at $3325 \mathrm{~cm}^{-1}$ and are 
205 calculated at $3637 / 3629 \mathrm{~cm}^{-1}$ and $3592 / 3573 \mathrm{~cm}^{-1}$ in CRN I/II, respectively. A difference in 206 wavenumber is observed in the calculated and observed IR mode of CRN. This lowering of 207 wavenumber from calculated to experimental value may be attributed to the hydrogen 208 bonding present in the experimental spectrum (solid state), whereas calculated spectrum is 209 plotted for the isolated molecule free from hydrogen bonds. Raman and IR peak at $632 \mathrm{~cm}^{-1}$ 210 and $651 \mathrm{~cm}^{-1}$ could be assigned to the out of plane bending of OH29. It is in excellent 211 agreement with calculated value at $631 / 636 \mathrm{~cm}^{-1}$.

212

\subsection{Natural Bond Orbital Analysis}

214 The NBO analysis has been performed in order to investigate the resonance structure contributions to molecules and also provides an efficient method to study intramolecular charge transfer interactions, rehybridization and delocalization of electron density (ED) within the molecule. The interaction of donor atom and acceptor will be stronger if $\mathrm{E}^{(2)}$ value is more [42-43]. When donation tendency from electron donors to electron acceptors is more, the extent of conjugation of the whole system is greater [44]. The hyperconjugative interaction energy was deduced from the second-order perturbation approach[45,46].

where, $\mathrm{q}_{\mathrm{i}}$ is the population of donor orbital or donor orbital occupancy; $\varepsilon_{\mathrm{i}}, \varepsilon_{\mathrm{j}}$ are orbital energies of donor and acceptor NBO orbitals, respectively; $F_{i j}$ is the off-diagonal Fock or

224 Kohn-Sham matrix element between $\mathrm{i}$ and $\mathrm{j}$ NBO orbitals. NBO analysis allowed us to investigate which orbital interactions are mainly involved in the stability of the molecule. The different types of donor-acceptor interactions and their stabilization energies are determined

227 by second order perturbation analysis of Fock matrix of CRN compound is presented in Table 228 2. 
229 The following different interactions responsible for the conjugation of the respective $\pi$-bonds 230 in the rings R1 and R2 of CRN have been computed with an interaction energy of about 22 $231 \mathrm{kcal} / \mathrm{mol}: \pi(\mathrm{C} 13-\mathrm{C} 15) \rightarrow \pi^{*}(\mathrm{C} 14-\mathrm{C} 16), \pi(\mathrm{C} 14-\mathrm{C} 16) \rightarrow \pi^{*}(\mathrm{C} 6-\mathrm{C} 12), \quad \mathrm{LP}(2) \mathrm{O} 1 \rightarrow \pi^{*}(\mathrm{C} 9-\mathrm{C} 10)$, $\mathrm{LP}(2) \mathrm{O} 2 \rightarrow \pi^{*}(\mathrm{C} 4-\mathrm{C} 7), \quad \pi(\mathrm{C} 4 \mathrm{C} 7) \rightarrow \pi^{*}(\mathrm{C} 8-\mathrm{C} 11), \quad \pi(\mathrm{C} 8-\mathrm{C} 11) \rightarrow \quad \pi^{*}(\mathrm{C} 9-\mathrm{C} 10), \quad \pi(\mathrm{C} 9-\mathrm{C} 10)$ $\rightarrow \pi^{*}(\mathrm{C} 4-\mathrm{C} 7)$. The $\pi(\mathrm{O} 3-\mathrm{C} 5) \rightarrow \pi^{*}(\mathrm{C} 6-\mathrm{C} 12)$ interaction has maximum interaction energy of $58.33 \mathrm{kcal} / \mathrm{mol}$ which is responsible for the stability of the carbonyl group.

Selected Lewis orbitals (occupied bond orbital) of CRN with percentage ED over bonded atoms $\left(E D_{X}, E_{Y}\right.$ in \%), hybrid NBOs with $\mathrm{s}$ and $\mathrm{p}$ character are listed in Table3. The valence hybrids analyses of NBOs show that all the O-C bond orbitals are polarized towards the Oxygen ( $72.69 \%$ at $\mathrm{O})$ atoms, however the $\mathrm{O} 29-\mathrm{H} 30$ bond orbitals are polarized towards the Oxygen atom (78.82\% at O). The electron density distribution (occupancy) about the $\mathrm{C}=\mathrm{O}$ group mainly affects the polarity of the compound. Consequently, they consist with the maximum electron density on the oxygen, Carbon atom and responsible for the polarity of the molecule.

\subsection{Chemical reactivity}

The chemical reactivity of the molecule has been described in two ways: (i) MEPS map, (ii) chemical reactivity descriptors.

\subsubsection{Molecular electrostatic potential surface}

The molecular electrostatic potential surface (MEPS) $[47,48]$ at a point $r$ in the space around a molecule (in atomic units) can be expressed as:

$$
\mathrm{V}(\mathrm{r})=\sum_{A} \frac{Z_{A}}{\left|\vec{R}_{A}-\vec{r}\right|}-\int \frac{\rho\left(\vec{r}^{\prime}\right) d r^{\prime}}{\left|\vec{r}^{\prime}-\vec{r}\right|}
$$


252 where $Z_{A}$ is the charge on nucleus $A$, located at $R_{A}$ and $\rho\left(r^{\prime}\right)$ is the electronic density function 253 for the molecule. The first and second terms represent the contributions to the potential due to 254 nuclei and electrons, respectively. $\mathrm{V}(\mathrm{r})$ is the resultant at each point $r$, which is the net 255 electrostatic effect produced at the point $r$ by both the electrons and nuclei of the molecule. 256 MEPS are used to predict thereactive sites for electrophilic attack and nucleophilic attack. 257 Three-dimensional MEPS superimposed onto the total electron density provides useful 258 information for the interpretation of long-range interaction between molecules, which helps 259 to understand how a ligand binds to its receptor. It provides a clear picture to understand 260 the relative polarity of a molecule and also gives the clear picture of the reactive sites of the 261 molecule. MEP surface are very helpful in which negative regions are regarded as 262 nucleophilic centres, whereas regions with positive electrostatic potential areregion 263 ofelectrophilic sites. Moreover, the electrostatic potential makes the polarization of the 264 electron density visible. Furthermore, they provide useful information on the shape and size 265 of the molecules [49].

266 MEP surface of CRN I and CRN II is presented in Fig.5. The red and blue region in the 267 MEPS refers to the electron rich and electron deprived region while green region suggests the 268 neutral region. The MEP surface shows that the most electronegative region is visible over $269 \mathrm{C}=\mathrm{O}$ group attached to ring $\mathrm{R} 1$ and $\mathrm{R} 2$ in both $\mathrm{CRN}$ I and $\mathrm{CRN}$ II. The most electropositive 270 region is localised on both $\mathrm{OH}$ group of ring R1 in case of CRN I whereas it is localised only 271 on $\mathrm{O} 29 \mathrm{H}$ group in CRN II. The orientation of O2H group is changed in case of CRN II, as $\mathrm{H}$ 272 atom of $\mathrm{O} 2 \mathrm{H}$ group is turned inwards. As a result no electropositive charge is localized there. 273 These are the reactive sites which are responsible for the chemical reactivity of CRN. 
276 In order to understand electronic transitions in terms of energies and oscillator strengths, the

277 TD-DFT/6-311++G(d,p)[20,21] calculations involving configuration interaction between the 278 singly excited electronic states were performed in the gaseous phase and in the DMSO 279 solution incorporating IEF-PCM model $[22,23]$. The UV-Vis spectrum of CRN is shown in 280 Fig. 6. Absorption band at $373 \mathrm{~nm}$ is observed in DMSO solvent. Both the frontier molecular 281 orbitals, highest occupied molecular orbital (HOMO) and lowest unoccupied molecular 282 orbital (LUMO) are the main orbitals taking part in chemical reaction. The electron 283 delocalization between HOMO and LUMO is the principle factor in determining the easiness 284 of a chemical reaction and the stereoselective path, irrespective of intra- and intermolecular 285 process.

286 To understand the electronic transitions, positions of experimental absorption peaks, 287 calculated wavelengths $\left(\lambda_{\max }\right)$, vertical excitation energies, oscillator strengths (f), dipole 288 moments, and excitation transition with spectral assignments for vacuum and solvent 289 environment are carried out. There was a difference observed in the transition orbital on 290 going from gaseous to solvent phase of CRN I. The transition observed in the UV spectrum is $291 \pi \rightarrow \pi^{*}$ and $\sigma \rightarrow \sigma^{*}$. The experimental absorption peak is observed at $373 \mathrm{~nm}$ corresponding the 292 theoretically calculated peak at 379 and $376 \mathrm{~nm}(\mathrm{H} \rightarrow \mathrm{L})$ in CRN I and CRN II with oscillator 293 strength of 0.0969 and 0.0951 in solvent phase and in gaseous phase it is calculated at 355 and $294376 \mathrm{~nm}(\mathrm{H} \rightarrow \mathrm{L})$ with oscillator strength of 0.0686 and 0.0651 (Table 4). This shows that the 295 calculations done in solvent phase are closer to the experimental results especially in case of 296 CRN I.

297 The HOMO and LUMO are the main orbitals that contribute towards the chemical stability 298 [50-51]. The energy gap between the HOMO and LUMO molecular orbitals characterizes the 299 chemical reactivity and kinetic stability along with spectroscopic properties [52]. Fig.7 shows 300 the energy gap between HOMO and LUMO for CRN I and II. In CRN I in case of HOMO, 
301 the charge density is largely on the R2 and carbonyl group while in case of CRN II HOMO 302 charge density is mainly accumulated on carbonyl group and partially on R1 and R2. On the 303 other hand in case of the LUMO more charge density moves to the R1, R2 and carbonyl 304 group for both CRN I and CRN II. The energy gap of HOMO and LUMO shows the 305 chemical strength of the molecule [53-55]. CRN I is chemically more active than CRN II, as 306 its band gap is less than the band gap of CRN II, which implies chemical stability of CRN II 307 is more than the chemical stability of CRN I.

\subsubsection{Electronic Reactivity descriptors}

Global reactivity descriptor helps in the prediction of electrophilic and nucleophilic reagent, whereas local reactivity descriptors help in the prediction of the site selectivity of electrophilic and nucleophilic attack as well as the order of preference.

\subsubsection{Local Reactivity descriptors}

The local reactivity parameters can be used to analyse the specific reactive sites within the molecule. Fukui function $\mathrm{f}(\mathrm{r})(\mathrm{FF})$ is widely used local reactivity parameter to identify the chemical reactivity and site selectivity of the molecule and is defined as the derivative of the electron density with respect to the total number of electrons $\mathrm{N}$ in the system, at constant external potential acting on an electron due to all the nuclei in the system. Thus, for an atom $\mathrm{k}$ in a molecule, three kinds of condensed FF, namely, $\mathrm{f}_{\mathrm{k}}{ }^{+}, \mathrm{f}_{\mathrm{k}}^{-}$and $\mathrm{f}_{\mathrm{k}}{ }^{0}$ can be used to describe the electrophilic, nucleophilic and radical reactivity, respectively, which are defined by equations in a finite difference approximation [56]. According to Parr and Yang [57], the sites which have highest values of Fukui function $f(r)$ are more reactive centres in chemical species.

325

For nucleophilic attack

$$
\mathrm{f}_{\mathrm{k}}^{+}(\mathrm{r})=\left[\mathrm{q}_{\mathrm{k}}(\mathrm{N}+1)-\mathrm{q}_{\mathrm{k}}(\mathrm{N})\right]
$$


326 For electrophilic attack

$$
\begin{aligned}
\mathrm{f}_{\mathrm{k}}^{-}(\mathrm{r}) & =\left[\mathrm{q}_{\mathrm{k}}(\mathrm{N})-\mathrm{q}_{\mathrm{k}}(\mathrm{N}-1)\right] \\
\mathrm{f}_{\mathrm{k}}^{0}(\mathrm{r}) & =1 / 2\left[\mathrm{q}_{\mathrm{k}}(\mathrm{N}+1)-\mathrm{q}_{\mathrm{k}}(\mathrm{N}-1)\right]
\end{aligned}
$$

328 Where $\mathrm{q}_{\mathrm{k}}$ is the gross electronic population of atom $\mathrm{k}$ in the molecule. Equations 4, 5 and 6 329 were employed to calculate the Fukui function values. In this case atomic charges derived 330 from Hirshfeld are used for the Fukui function calculation (Table5). The most susceptible site 331 for an electrophilic and nucleophilic attack is $\mathrm{O} 3$ and $\mathrm{O} 29$, respectively in both the 332 conformers. For a free radical attack the most reactive site is C17 in cases of CRN I and C5 in 333 CRN II.

\subsubsection{Global reactivity descriptors}

On the basis of Koopman's theorem [58], electrophilicity encompasses both the ability of an

337 electrophile to acquire additional electronic charge and the resistance of the system to exchange electronic charge with the environment. It contains information about both electron transfer (chemical potential) and stability (hardness) and is the better descriptor of global chemical reactivity. Global reactivity descriptors such as electronegativity $(\chi)$, chemical potential $(\mu)$, global hardness $(\eta)$, global softness $(S)$ and global electrophilicity index $(\omega)$ are calculated using the energies of frontier molecular orbitals $\varepsilon_{\mathrm{HOMO}}$, $\varepsilon_{\mathrm{LUMO}}$ and given by eqs.[59-63].

$$
\begin{gathered}
\chi=-\frac{1}{2}\left(\epsilon_{\text {HOMO }}+\epsilon_{\text {LUMO }}\right) \\
\mu=-\chi=\frac{1}{2}\left(\epsilon_{\text {HOMO }}+\epsilon_{\text {LUMO }}\right) \\
\eta=\frac{1}{2}\left(\epsilon_{L U M O}-\epsilon_{\text {HOMO }}\right) \\
\omega=\frac{\mu^{2}}{2 \eta} \\
S=\frac{1}{2 \eta}
\end{gathered}
$$


349 According to Parr et al [64], $\omega$ is a global reactivity index similar to $\mu$ and $\eta$. This is positive 350 and definite quantity. This new reactivity index measures the stabilization in energy when the 351 system acquires an additional electronic charge $(\Delta N)$ from the environment. The direction of 352 the charge transfer is completely determined by the electronic chemical potential of the 353 molecule because an electrophile is a chemical species capable of accepting electrons from 354 the environments. Therefore its energy must decrease upon accepting electronic charge and 355

\subsection{Molecular docking}

Molecular docking is a significant tool in structural molecular biology and computer-assisted drug design. The aim of ligand-protein docking is to predict the predominant binding mode(s) of a ligand with a protein of known three-dimensional structure $[65,66]$. Peroxisome Proliferator-active Protein is used for the prevention and treatment of inflammation-related diseases. Crystal structure of Peroxisome Proliferator-active (anti-inflammatory) and DCD-1 (anti-microbial) bacterial protein is downloaded from RSCB PDB website (PDB code: 4XTA-B and 2YMK-C [67]. The active site of the enzyme was defined to include residues of the active site within the grid size of $60 \AA \times 60 \AA \times 60 \AA$. The protein was prepared by removing the waters, co-crystallized ligands, co-factors and Lamarckian Genetic Algorithm (LGA) available in AutoDock was employed for docking [68]. Out of all the docked conformations, one which bound well at the active site was examined for detailed interactions in Discovery Studio Visualizer 4.5 software[28] and shown in Fig. 8 and Fig. 9. Two proteins of E. coli 
374 were studied. Protein (Peroxisome Proliferator-active)-ligand interaction shows that there are 375 three conventional H-bond with amino acids: Asp-B:441(1.70 $\AA$ ),Lys-B:(2.21 $\AA)$ interact with 376 OH group of ring $\mathrm{R} 1$ and $\mathrm{Thr}-\mathrm{B}: 440(2.56 \AA)$ interact with $\mathrm{C}=\mathrm{O}$ group attached to ring $\mathrm{R} 1$ and 377 R2 of CRN (Fig. 8). Other interactions were also observed such as pi-cation (Asp-A:396, $3784.96 \AA$ ), pi-Anion (Arg-A:443, $3.55 \AA$ ), and pi- alkyl (Ile-A:391, $4.98 \AA$, Met-A:439, $4.08 \AA$ )

380 DCD-1 protein shows antimicrobial activity thereby limiting skin infection diseases. Second 381 protein (DCD-1) - ligand interaction reveals that protein interacts with amino acids through 382 four conventional H-bonds.Lys-B:34, (2.08 $\AA, 2.13 \AA$ ) interacts with $\mathrm{C}=\mathrm{O}$ group and $\mathrm{OH}$ 383 group of ring R1. Glu-A:30, (2.05 Å) interact with OH group of ring R1, Lys-A:34(1.91 $384 \AA$ )interact with $\mathrm{OH}$ group present in R1 (Fig. 9). Pi-alky (LysA:4, $5.02 \AA$ ) interactions are 385 also observed. The ligand CRN forms a stable complex with Peroxisome Proliferator-active and DCD-1 having binding energy -6.55 and $-3.73 \mathrm{kcal} / \mathrm{mol}$, respectively. Peroxisome 387 Proliferator-active has larger binding energy than DCD-1 which shows that it has strong interactions with the ligand. The result of docking as well as local reactivity descriptors are same having $\mathrm{O}-\mathrm{H}$ and $\mathrm{C}=\mathrm{O}$ as prominent reactive sites.

\section{Conclusions}

392 In the present study the experimental and theoreticalanalysis of the possible conformations of 393 the cearoin $(\mathrm{CRN})$ has been reported. Comprehensive assignments of the vibrational spectra 394 of the most stable conformers have been made with the aid of theoretically predicted 395 vibrational wavenumbers. Finally, the calculations were done for the two most stable 396 conformers that are similar in geometry except for the orientation of the methoxy group, $\mathrm{OH}$ 397 group and ring 2 of. Further the calculated results of both the conformers are used to simulate 398 infrared and Raman spectra which showed good agreement with observed spectra. NBO 
399 analysis shows that O3 (oxygen) atom has the most intensive interaction in between the 400 acceptor and the donor. From the HOMO-LUMO energy gap and global reactivity 401 parameters, it is clear that cearoinI (CRN I) is more reactive and having high value of global 402 softness than cearoin II (CRN II). MEPS was plotted for predicting the electronic properties. 403 The absorption peaks are recorded at $373 \mathrm{~nm}$ in UV-Vis spectrum which has transition from $404 \mathrm{H} \rightarrow \mathrm{L}\left(\pi \rightarrow \pi^{*}\right)$. Fukui calculations show that $\mathrm{O} 3$ and $\mathrm{O} 29$ are susceptible for nucleophilic and 405 electrophilic attack for both the conformers where as for free radical attack the most reactive 406 site is $\mathrm{C} 17$ (carbon) for CRN I and C5 for CRN II. Molecular docking simulation shows 407 protein-ligand interactions by means of $\mathrm{H}$-bond. The $\mathrm{C}=\mathrm{O}$ and $\mathrm{OH}$ groups binding the protein 408 conventionally.

\section{Acknowledgements}

410 Shweta and Eram Khan are thankful to UGC, New Delhi for providing financial assistance 411 UGC-RGN fellowship and UGC-BSR fellowship, respectively. Poonam Tandon is thankful 412 to the DST for financial support under Indo-Brazil project. 

$\phi 6$ of CRN.

Fig. 2 Optimized structure for CRN I and CRN II with the atoms number.

Fig. 3 Observed and calculated infrared spectra of CRN in the region $400-1000 \mathrm{~cm}^{-1}$,

436 Fig. 4 Observed and a calculated Raman spectra of CRN in the region $100-900 \mathrm{~cm}^{-1}$, $900-1800$ and $2801-3800 \mathrm{~cm}^{-1}$.

Fig. 5 Molecular electrostatic potential (MESP) formed by mapping of total density over electrostatic potential of CRN I and CRN II.

440 Fig. 6 Experimental UV-Visible spectra of CRN in DMSO solvent.

441 Fig. 7 HOMO-LUMO plots for CRN I and CRN II.

442 Fig.8 Docking of CRN with the molecular target Peroxisome Proliferator-active.

443 Fig. 9 Docking of CRN with the molecular target DCD-1.

$444 \quad$ Fig.S1 List of all the conformers with their optimized structure along with their energies.

445 Fig.S2 Comparison of the experimental and the optimized structure of CRN I and CRN II 446 (hydrogen atoms are not shown).

447 Table 1 Theoretical and experimental vibrational wavenumbers $\left(\mathrm{cm}^{-1}\right)$ of CRN with potential 448 energy distribution (PED). 
449 Table 2 Second order perturbation theory analysis of Fock matrix in NBO Basis for CRN.

450 Table 3 Selected Lewis orbitals (occupied bond orbital) with percentage ED over bonded 451 atoms $\left(\mathrm{ED}_{\mathrm{X}}, \mathrm{ED}_{\mathrm{Y}}\right.$ in \%), hybrid NBOs with $\mathrm{s}$ and $\mathrm{p}$ character in \% for CRN.

452 Table 4 Electronic transitions, absorption wavelength $\lambda_{\max }(\mathrm{nm})$, excitation energy $(\mathrm{eV})$ and 453 oscillator strengths (f) of CRN I and CRN II.

454 Table 5 Calculated local reactivity properties of the selected atoms using Hirshfeld $455[\mathrm{~B} 3 \mathrm{LYP} / 6-311++\mathrm{G}(\mathrm{d}, \mathrm{p})]$ derived charges of CRN I and CRN II.

456 Table 6 Calculated $\varepsilon_{\mathrm{HOMO}}, \varepsilon_{\mathrm{LUMO}}$, energy band gap $\left(\varepsilon_{\mathrm{H}}-\varepsilon_{\mathrm{L}}\right)$, chemical potential $(\mu)$, 457 electronegativity $(\chi)$, global hardness $(\eta)$, global softness (S) and global electrophilicity index $458(\omega)$ at $298.15 \mathrm{~K}$ of CRN I and CRN II.

459 Table S1 Ground state optimized energy and energy difference of all the four conformers of 460 CRN.

461 Table S2 Comparison of bond length $\AA$, bond angle $\left({ }^{\circ}\right)$ and dihedral angle $\left({ }^{\circ}\right)$ of the two 462 conformers of CRN by DFT method using 6-311++g(d,p). 


\section{References}

480 [1] R. Maurya, P. Dixit, R. Trivedi, V. Khedgikar, J. Gautam, A. Kumar, D. Singh, S.P. 481 Singh, Wahajuddin, G.K. Jain, N. Chattopadhyay, Pub.No.: US 2014/0079834 A1, 1-23.

482 [2] P. Kumara, P. Kushwahab, V. Khedgikarb, J. Gautamb, D. Choudhary, D. Singh , R. 483 Trivedi, and R. Maurya. Bioorgenic Medicinal Chemistry Letters, 24(12), 2664, (2014).

484 [3]N.Muangnoicharoen, A.W. Frahm. Neoflavonoids of Dalbergiaparviflora.Phytochemistry, $48521,761,(1982)$.

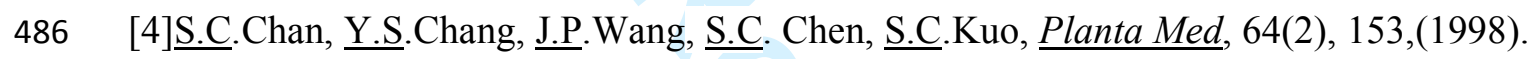

487 [5]A. E.Khaleel, S. H. El-Gayed,A. Al-AzharAmeen, J. Pharm. Sci, , 28, 285, (2001).

488 [6] P. K.Niranjan,D. Singh, K.Prajapati, S. K. Jain, Int. J. Curr. Pharm. Res, 2, 24, (2010).

489 [7]P.Dixit, R.Chillara, V.Khedgikar,J.Gautam, P.Kushwaha, A.Kumar, D.Singh, R.Trivedi, 490 R.Maurya, Bioorg. Med. Chem. Let, 22, 890, (2012).

491 [8]V. K.Ahlumalia, T. R.Seshadri, Curr.Sci, 32, 455, (1963).

492 [9]S. K.Jain, A.Roberts, Defilipps, 1, 325 (1991).

493 [10]H.Yadav, M.Yadav, S.Jain, A.Bhardwaj,V.Shing, O.Parkash, F.Marotta, Int. J. 494 Immunopath. Pharmocol, 21, 1013, (2008).

495 [11]T.M. Lakshmi, R.Radha, N. Jayshree, Journal of Pharmaceutical Research \& Clinical 496 Practice, 4(1), 53, (2014).

497 [12]M.Kuroda, S.Uchida, K.Watanabe, Y.Mimaki, Chromones from the tubers of 498 Eranthiscilicica and their antioxidant activity, Phytochemistry, 70, 288, (2009).

499 [13]S.Sultana, H.M.Asif, N.Akhtar, N.Akhtar, Journal of Pharmacognosy and 500 Phytochemistry, 2(9), 440, (2015).

501 [14]M.J. Frisch, G.W. Trucks, H.B. Schlegel. G.E. Scuseria, J.R. Cheeseman, M.A. Robb, G. 502 Scalmani, V. Barone, B. Mennucci, G.A. Petersson, H. Nakatsuji, M. Caricato, X. Li, H.P. 503 Hratchian, A.F. Izmzylov, J. Bloino, G. Zheng, J.L. Sonnenberg, M. Hada, M. Ehara, K. 504 Toyota, R. Fukuda, J. Ishida, M. Hasegawa, T. Nakajima, Y. Honda, O. Kitao, H. Nakai, T. 505 Vreven, J.A. Montgomery Jr., J.E. Peralta, F. Ogliaro, M. Bearpark, J.J. Heyd, E. Brothers, 
506 K.N. Kudin, V.N. Staroverov, R. Kobayashi, J. Normand, A. Raghavachari, A. Rendell, J.C. 507 Burant, S.S. Iyengar, J. Tomasi, M. Cossi, N. Rega, J.M.Millan, M. Klene, J.E. Knox, J.B. 508 Cross, V. Bakken, C. Adamo, J. Jaramillo, R. Gomperts, R.E. Stratmann, O. Yazyev, A.J. 509 Austin, R. Cammi, C. Pomelli, J.W. Ochterski, R.L. Martin, K. Morokuma, V.G. Zakrzewski, 510 G.A. Voth, P. Salvador, J.J. Dannerberg, S. Dapprich, A.D. Daniels, J. Farkas, B. Foresman, 511 J.V. Ortiz, J. Cioslowski, D.J. Fox, GAUSSIAN 09, Revision, Gaussian, Inc., Wallingford 512 CT, 2009.

513 [15]C.T. Lee, W.T. Yang, R.G. Parr, Phys. Rev. B, 37, 785, (1988).

514 [16] A.D. Becke, J. Chem. Phys., 98, 5648, (1993).

515 [17] R.G. Parr, W. Yang, Density Functional Theory of Atoms and Molecules, Oxford 516 University Press, New York, (1989).

517 [18] P.J. Stephens, F.J. Devlin, C.F. Chabalowski, M.J. Frisch, J. Phys. Chem., 198, (1623), 518 (1994)

519 [19]L.Zhenjiang, H.Wan, Y.Shi, and P.Ouyang J. Chem. Inf. Comput. Sci., 44 (5), (1886), 520 (2004).

521 [20] P. Hohenberg, W. Kohn, Phys. Rev. B, 136, 864, (1964).

522 [21]W. Kohn, L. Sham, Phys. Rev. A, 140,1133 , (1965).

523 [22] E. Cances, B. Mennucci, J. Tomasi, J. Chem. Phys., 107, 3032, (1997).

524 [23]B. Mennucci, J. Tomasi, J. Chem. Phys, 106, 5151, (1997).

525 [24]G.A. Zhurko, D.A. Zhurko, Chemcraft, 2005, http://www.chemcraftprog.com.

526 [25]A.Frisch, A.B. Nielson, A.J. Holder, GaussView User Manual, Gaussian Inc, Pittsburgh, 527 P.A., (2005).

528 [26]J.M.L. Martin, C.VanAlsenoy, Gar2ped, University of Antwerp, Antwerp, (1995).

529 [27]P. Pulay, G. Fogarasi, F. Pang, J.E. Boggs, J. Am. Chem. Soc., 101, 2550, (1979).

530 [28]G. Fogarasi, X. Zhou, P.W. Taylor, P. Pulay, J. Am. Chem.Soc., 114, 8191, (1992).

531 [29]O. Trott, A.J. Olson, J. Comput. Chem. , 31, 455, (2010).

532 [30]Discovery Studio 4.5 Guide, Accelrys Inc., San Diego, http://www.accelrys.com, (2009).

533 [31]G.A. Guirgis, P. Klaboe, S. Shen, D.L. Powell, A. Gruodis, V. Aleksa, C.J. Nielsen, J.

534 Tao, C. Zheng, R.J. Durig, J. Raman Spectrosc, 34, 322, (2003).

535 [32]P.L. Polavarapu, J. Phys. Chem., 94, 8106, (1990).

536 [32] H. Yoshida, K. Takeda, J. Okamura, A. Ehara, H. Matsurra, J. Phys. Chem., A, 106, $5373580,(2002)$.

538 [34]M.W. Wong, Chem. Phys. Lett, 256, 391, (1996).

539 [35]A.P. Scott, L. Radom, J. Phys. Chem., 100, 16502, (1996). 
540 [36] J.R. Scherer, Spectrochim. Acta, 19, 601, (1963).

541 [37] J.R. Scherer, Spectrochim. Acta , 21, 321, (1965).

542 [38] G. Varsanyi, Assignments for Vibrational Spectra of Seven Hundred Benzene 543 Derivatives, ,AcademicKiado, Budapest, 1 and 2, (1973).

544 [39] Silverstein, R.M.; Bassler, G.C.; and Morrill, T.C. Spectrometric Identification of 545 Organic Compounds. 4th ed. New York: John Wiley and Sons, 1981. QD272.S6 S55

546 [40] Nakanishi, Koji Infrared Absorption Spectroscopy. QD95.N383.

547 [41] N.B. Colthup, L.H. Daly, S.E. Wiberley, Introduction to Infrared and Raman 548 Spectroscopy, Academic Press, New York, (1990).

549 [42] F. Weinhold, C. R. Landis, Chemistry Education: Research and Practice, 2291,(2001).

550 [43] J. P. Foster, F. Weinhold, Journal of the American Chemical Society, 102, 7211, (1980,.

551 [44] E. D. Glendening, F. Weinhold, Journal of Computational Chemistry, 19, 6593, (1998).

552 [45] N. Gonohe, H. Abe, N. Mikami, M. Ito, J. Phys. Chem., 89, 3642, (1985).

553 [46] M. Gutowski, G. Chalasinski, J. Chem. Phys., 98, 4540, (1993).

554 [47] K. Paul.Weiner, R.Langridge, M.J.Blaney, R.Schaefer, A. Kollman.Peter. Proc. 555 NatiAcad. Sci. USA, 79, 3754, (1982).

556 [48] S. Chidangil, M.K. Shukla, P.C. Mishra, J. Mol. Model, 4, 250, (1998).

557 [49] M. Kumru, V. Kucuk, M. Kocademir, H.M. Alfanda, A. Altun, L. Sar1, Spectrochim. 558 ActaA Mol. Biomol. Spectrosc., 134, 81,(2015).

559 [50] S. Gunasekaran, R.A. Balaji, S. Kumaresan, G. Anand, S. Srinivasan, Can. J. Anal. Sci. 560 Spectrosc., 53, 149,(2008).

561 [51] K. Fukui, Science, 218,747, (1982).

562 [52] P.W. Atkins, Physical Chemistry, Oxford University Press, Oxford, 2001.

563 [53] K. Fukui, T. Yonezawa and H. Shingu, J. Chem. Phys, 20,722,(1952).

564 [54] D. F. V. Lewis, C. Ioannides, D. V. Parke, Xenobiotica, 24, 401, (1994).

565 [55] D. C. Ghosh, J. Jana, Current Science, 4, 76,(1999).

566 [56] Parr, R. G.; Yang, W. J. Am. Chem. Soc. 106, 4049,(1984). (b)Yang, Y.;Parr, R. G. 567 Proc. Natl. Acad. Sci. U.S.A. 821, 6723, (1985).

568 [57] Parr, R. G.; Szentpaly, L. V.; Liu, S. J. Am. Chem. Soc., 121, 1922 (1999). (b) Chattaraj,

569 P. K;Sarkar, U.; Roy, D. R. Chem. ReV. 106, 2065, (2006).

570 [58]R.G. Parr, W. Yang, Density Functional Theory of Atoms and Molecules, Oxford 571 University Press, New York, (1989).

572 [59]R.G. Pearson, J. Org. Chem.,54 1430,( 1989).

573 [60]R.G. Parr, R.G. Pearson, J. Am. Chem. Soc., 105, 7512, (1983). 
574 [61]P. Geerlings, F.D. Proft, W. Langenaeker, Chem. Rev, 103, 1793, (2003).

575 [62]R.G. Parr, L. Szentpaly, S. Liu, J. Am. Chem. Soc.,121, 1922, (1991).

576 [63]P.K. Chattaraj, U. Sarkar, D.R. Roy, Chem. Rev, 106, 2065,( 2006).

577 [64] R.G. Parr, L. Szentpaly, S. Liu, J. Am. Chem. Soc., 121, 1922,( 1991).

578 [65]Y.Sheena.Mary, C.YohannanPanicker, T.Thiemann, M.Al-Azani, A.Al-Saadi, 579 C.VanAlsenoy, K. Raju, J.Ahmad War, S.K. Srivastava, 151, 350,( 2015).

580 [66]A. Shukla, E. Khan, A. Srivastava, P. Tandon and K. Sinha,Mol. Simul., 42, 863,(2015).

581 [67] X. Giu, C.A. Janson, R.I. Court, M.G. Smyth, D.J. Payne, S.S.A. Megurd, Protein Sci., $5828,2529,(1999)$.

583 [68]G.M. Morris, D.S. Goodsell, R.S. Halliday, R. Huey, W.E. Hart, R.K. Belew, A.J. 584 Olson,J. Comput. Chem, 19, 1639, (1998). 

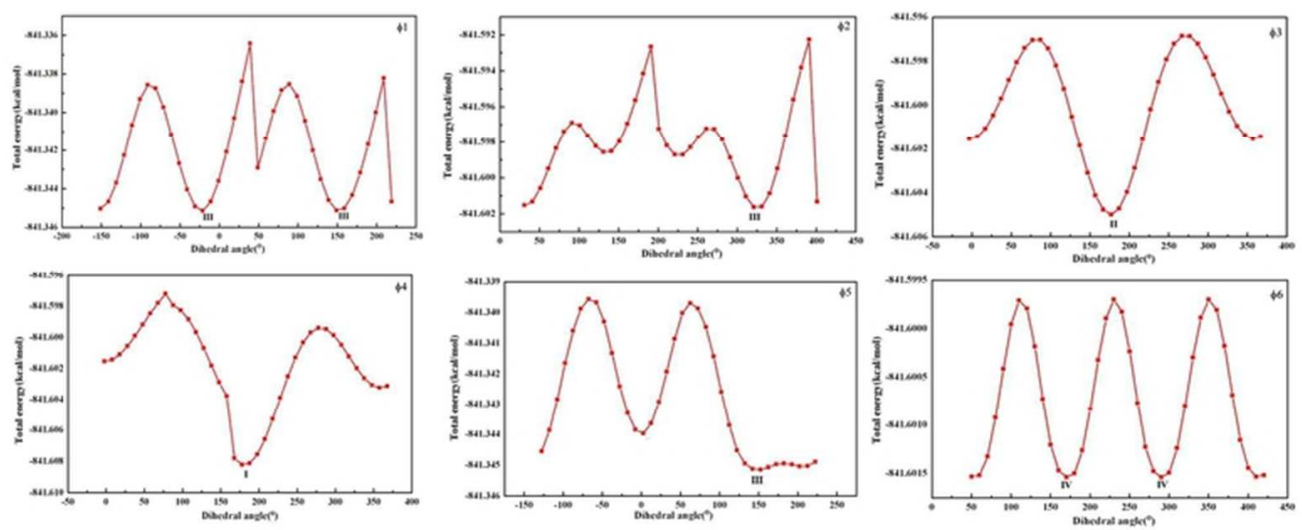

Potential energy surface scan with varying dihedral angle $\phi 1, \phi 2, \phi 3, \phi 4, \phi 5$ and $\phi 6$ of CRN.

$32 \times 13 \mathrm{~mm}(600 \times 600$ DPI $)$ 


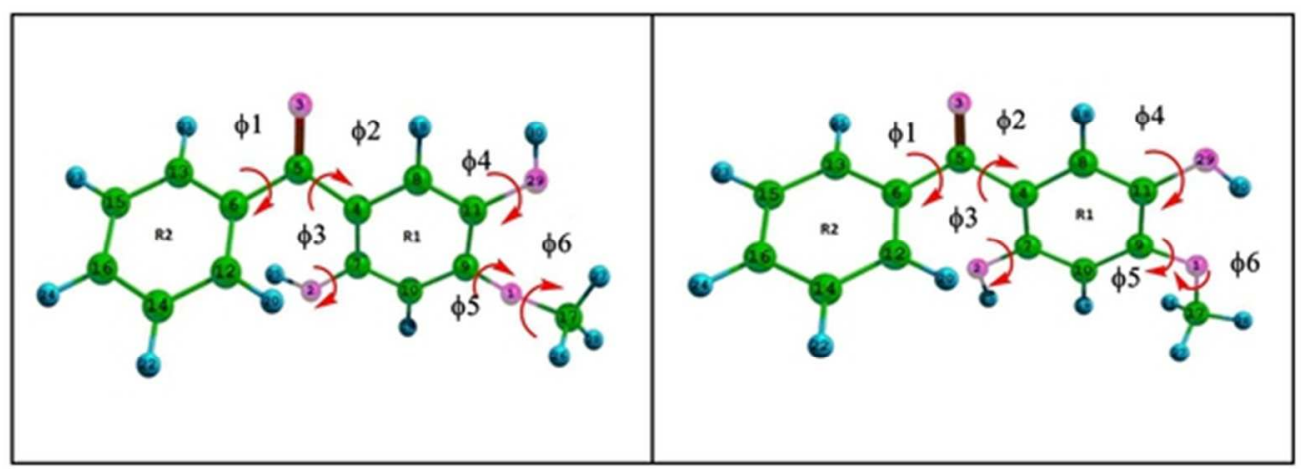

Optimized structure for CRN I and CRN II with the atoms number $24 \times 8 \mathrm{~mm}(600 \times 600 \mathrm{DPI})$ 
Canadian Journal of Physics

Page 26 of 39

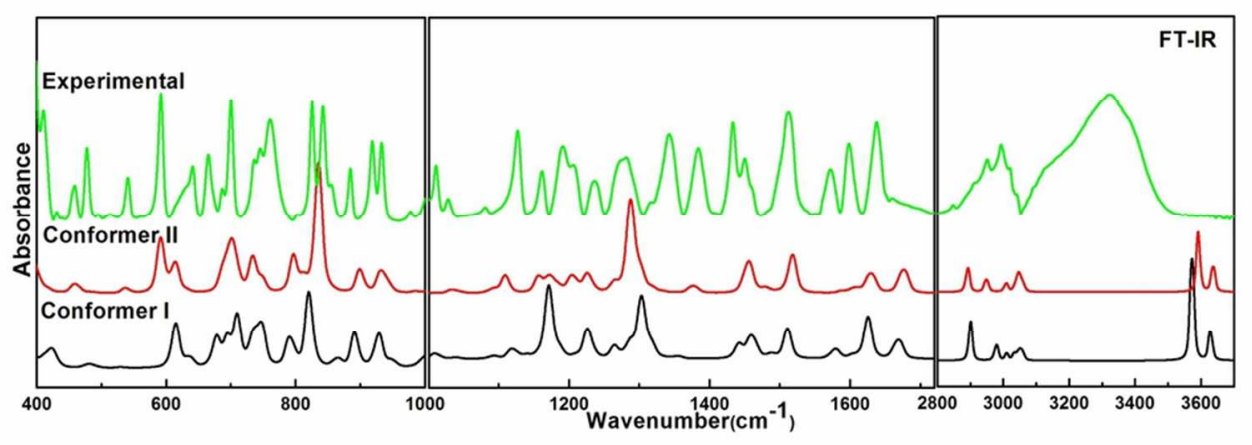

Observed and calculated infrared spectra of CRN in the region $400-1000 \mathrm{~cm}-1,1001-1720 \mathrm{~cm}-1$ and $2800-$ $3700 \mathrm{~cm}-1$.

$41 \times 14 \mathrm{~mm}(600 \times 600 \mathrm{DPI})$

https://mc06.manuscriptcentral.com/cjp-pubs 


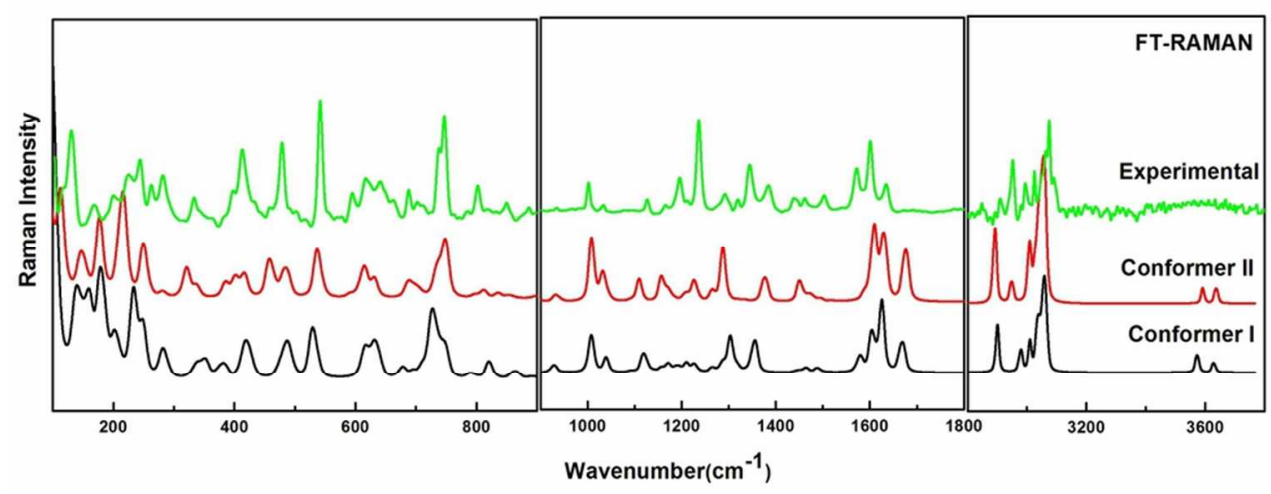

Observed and a calculated Raman spectra of CRN in the region $100-900 \mathrm{~cm}-1,900-1800$ and $2801-3800 \mathrm{~cm}-$ 1.

$42 \times 16 \mathrm{~mm}(600 \times 600 \mathrm{DPI})$ 


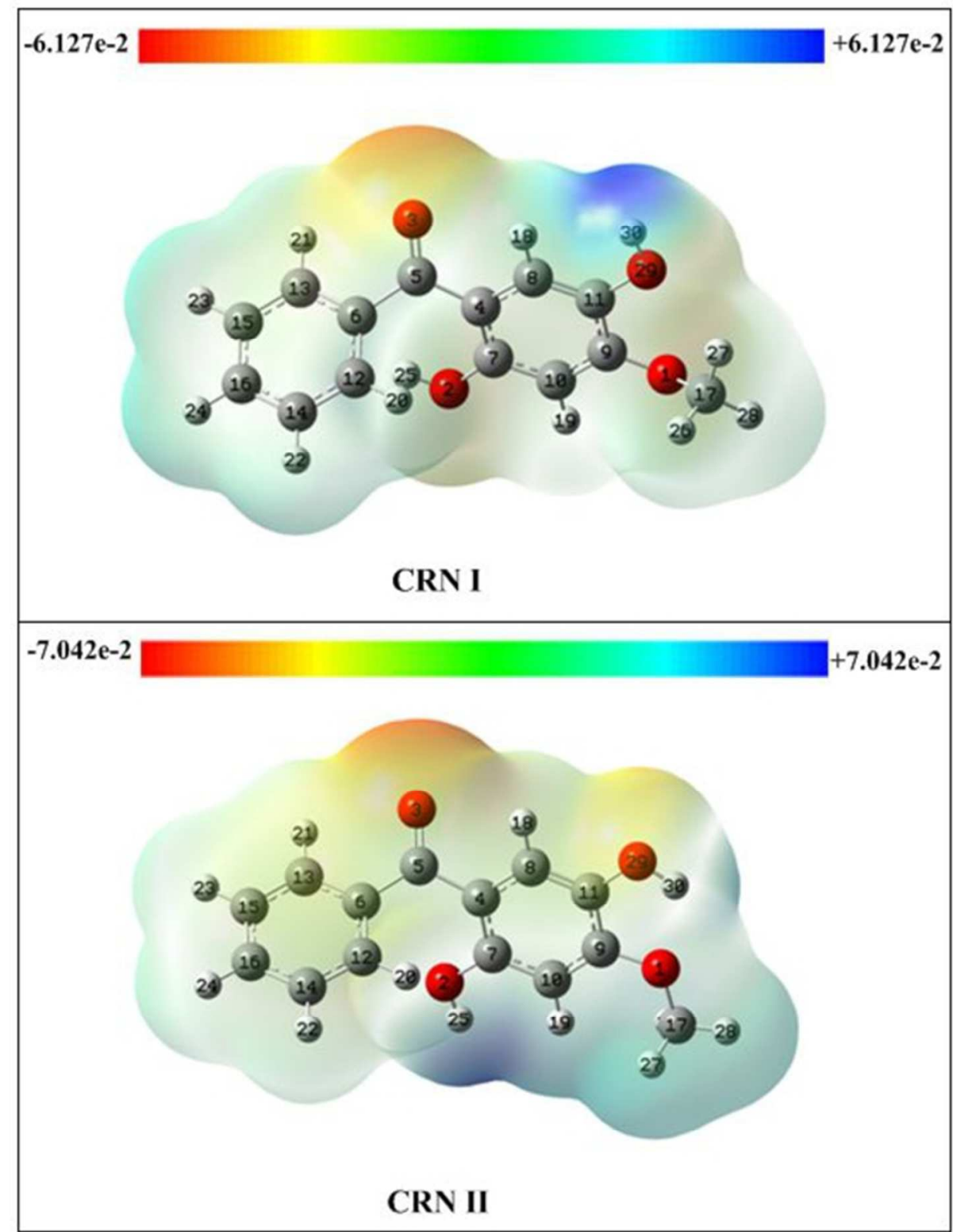

Molecular electrostatic potential (MESP) formed by mapping of total density over electrostatic potential of CRN I and CRN II.

$28 \times 36 \mathrm{~mm}(600 \times 600 \mathrm{DPI})$ 


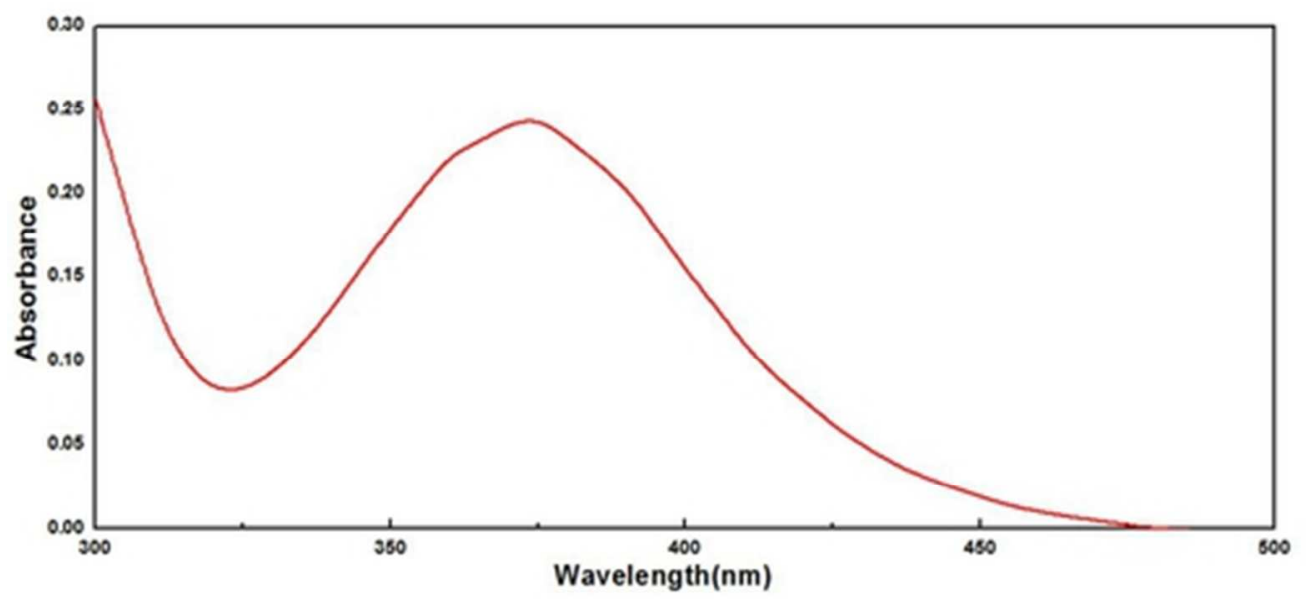

Experimental UV-Visible spectra of CRN in DMSO solvent.

$21 \times 10 \mathrm{~mm}(600 \times 600 \mathrm{DPI})$ 


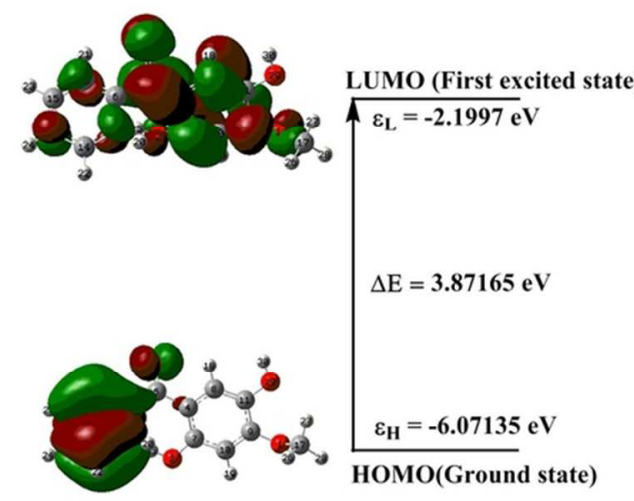

Conformer I

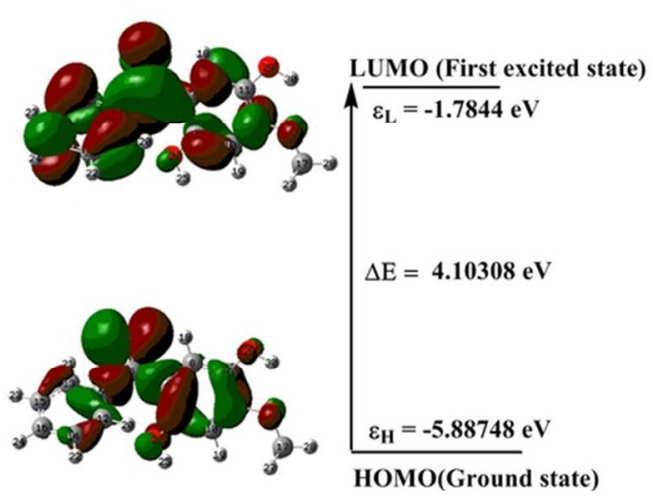

Conformer II

HOMO-LUMO plots for CRN I and CRN II.

$38 \times 18 \mathrm{~mm}(600 \times 600$ DPI $)$ 


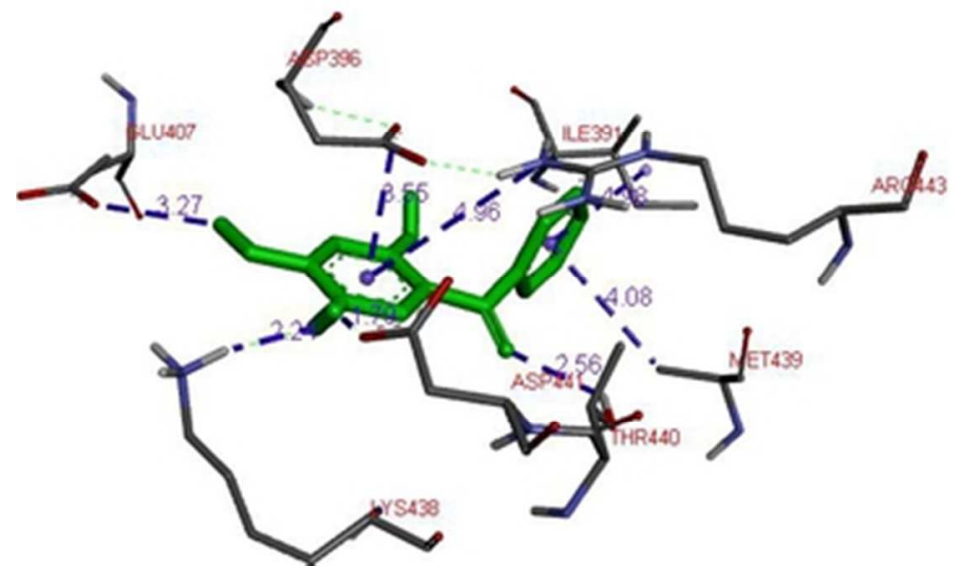

Docking of CRN with the molecular target Peroxisome Proliferator-active.

$15 \times 9 \mathrm{~mm}(600 \times 600 \mathrm{DPI})$ 


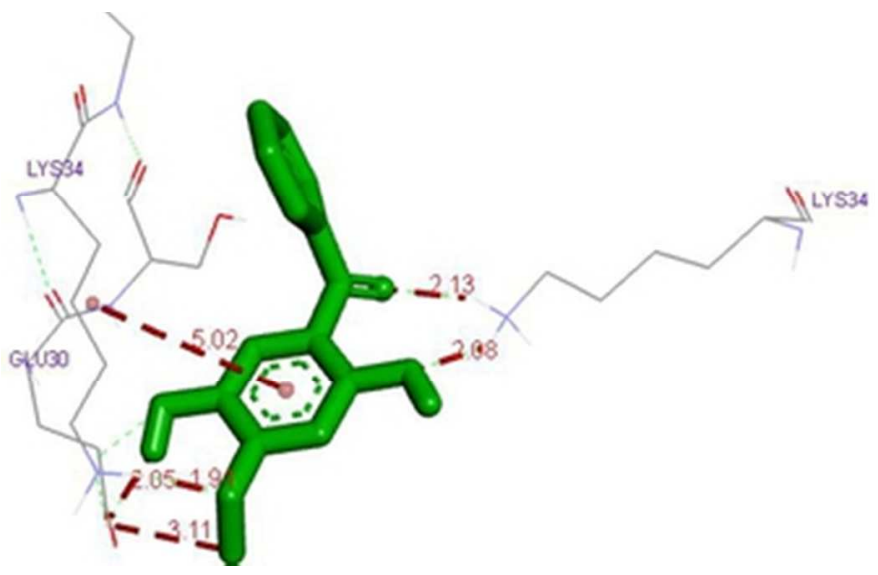

Docking of CRN with the molecular target DCD-1.

$14 \times 8 \mathrm{~mm}(600 \times 600 \mathrm{DPI})$ 
Table 1

Theoretical and experimental vibrational wavenumbers $\left(\mathrm{cm}^{-1}\right)$ of $\mathrm{CRN}$ with potential energy distribution (PED).

\begin{tabular}{|c|c|c|c|c|c|}
\hline \multirow{2}{*}{$\begin{array}{c}\text { Unscaled } \\
\text { DFT } \\
\text { CRN I }\end{array}$} & \multicolumn{2}{|c|}{ Scaled } & \multicolumn{2}{|c|}{ Experimental } & \multirow{2}{*}{ Assignment } \\
\hline & CRN I & CRN II & IR & RAMAN & \\
\hline 3844 & 3637 & 3629 & 3325 & - & $v(\mathrm{O} 2 \mathrm{H})(93)+v(\mathrm{O} 29 \mathrm{H})(7)$ \\
\hline 3794 & 3592 & 3573 & & - & $v(\mathrm{O} 29 \mathrm{H})(93)+v(\mathrm{O} 2 \mathrm{H})(7)$ \\
\hline 3204 & 3064 & 3066 & 3096 & 3090 & $\mathrm{R} 2\left[\mathrm{v}_{\mathrm{s}}(\mathrm{CH})\right](93)$ \\
\hline 3198 & 3059 & 3060 & 3076 & 3075 & $\mathrm{R} 2\left[v_{\mathrm{a}}(\mathrm{CH})\right](99)$ \\
\hline 3192 & 3053 & 3054 & & 3063 & $\mathrm{R} 2\left[\mathrm{v}_{\mathrm{a}}(\mathrm{CH})\right](96)$ \\
\hline 3182 & 3045 & 3046 & 3042 & & $\mathrm{R} 2\left[v_{\mathrm{a}}(\mathrm{CH})\right](94)$ \\
\hline 3180 & 3043 & 3038 & & & $\mathrm{R} 1\left[v_{\mathrm{s}}(\mathrm{CH})\right](99)$ \\
\hline 3172 & 3036 & 3032 & 3020 & 3025 & $\left.\mathrm{R} 1\left[v_{\mathrm{a}}(\mathrm{CH})\right)\right](99)$ \\
\hline 3161 & 3026 & 3031 & 2993 & 2994 & $\mathrm{R} 2\left[v_{\mathrm{a}}(\mathrm{CH})\right](94)$ \\
\hline 3141 & 3008 & 3010 & & 2980 & {$\left[v_{\mathrm{a}}\left(\mathrm{CH}_{3}\right)\right](99)$} \\
\hline 3076 & 2949 & 2979 & 2951 & 2953 & {$\left[v_{a}\left(\mathrm{CH}_{3}\right)\right](99)$} \\
\hline 3013 & 2892 & 2900 & 2910 & 2911 & {$\left[v_{\mathrm{s}}\left(\mathrm{CH}_{3}\right)\right](99)$} \\
\hline 1708 & 1676 & 1668 & 1638 & 1634 & $v(\mathrm{C}=\mathrm{O})(75)+\delta_{\text {in }}(\mathrm{C} 5 \mathrm{C} 6)(5)$ \\
\hline 1660 & 1630 & 1625 & & & $\mathrm{R} 1\left[v(\mathrm{CC})(63)+\delta^{\prime}{ }_{a}(\mathrm{O} 1 \mathrm{C} 9)(10)\right]$ \\
\hline 1638 & 1608 & 1605 & 1599 & & $\mathrm{R} 2\left[v(\mathrm{CC})(57)+\delta_{\text {in }}(\mathrm{C} 12 \mathrm{H})(7)\right]+\mathrm{R} 1\left[\delta_{\mathrm{a}}(\mathrm{O} 1 \mathrm{C} 17)(9)\right]$ \\
\hline 1634 & 1604 & 1585 & & 1601 & $\mathrm{R} 1\left[v(\mathrm{CC})(56)+\delta_{\mathrm{a}}(\mathrm{O} 1 \mathrm{C} 9)(10)\right]$ \\
\hline 1618 & 1589 & 1578 & 1572 & 1570 & $\mathrm{R} 2\left[v(\mathrm{CC})(66)+\delta_{\mathrm{in}}(\mathrm{C} 16 \mathrm{H})(10)\right]+\mathrm{R} 1\left[\delta^{\prime}{ }(\mathrm{O} 1 \mathrm{C})(9)\right]$ \\
\hline 1543 & 1517 & 1511 & 1512 & 1503 & $\mathrm{R} 1\left[\delta_{\text {in }}(\mathrm{CH})(28)+v(\mathrm{C} 9 \mathrm{C})(27)+v(\mathrm{O} 1 \mathrm{C})(9)\right]$ \\
\hline 1520 & 1495 & 1493 & & & $\mathrm{R} 2\left[\delta_{\text {in }}(\mathrm{C} 15 \mathrm{H})(60)+v(\mathrm{C} 15 \mathrm{C})(37)\right]$ \\
\hline 1505 & 1482 & 1486 & & 1503 & $\delta_{\mathrm{a}}\left(\mathrm{CH}_{3}\right)(80)+\delta_{\mathrm{a}}{ }^{\prime}\left(\mathrm{CH}_{3}\right)(9)+\rho\left(\mathrm{CH}_{3}\right)(5)+\rho^{\prime}\left(\mathrm{CH}_{3}\right)(5)$ \\
\hline 1493 & 1470 & 1465 & & & $\delta_{\mathrm{a}}^{\prime}\left(\mathrm{CH}_{3}\right)(79)+\delta_{\mathrm{a}}\left(\mathrm{CH}_{3}\right)(8)$ \\
\hline 1480 & 1457 & 1460 & 1460 & 1460 & $\delta_{\mathrm{s}}\left(\mathrm{CH}_{3}\right)(54)+\mathrm{R} 2\left[\delta_{\text {in }}(\mathrm{C} 16 \mathrm{H})(6)\right]$ \\
\hline 1478 & 1455 & 1452 & 1450 & & $\left.\delta_{\mathrm{s}}\left(\mathrm{CH}_{3}\right)(20)\right]+\mathrm{R} 1\left[\delta_{\text {in }}(\mathrm{CH})\right](41)+v(\mathrm{CC})(19)$ \\
\hline 1473 & 1450 & 1441 & 1433 & 1439 & $\mathrm{R} 1[v(\mathrm{CC})](33)+\delta_{\mathrm{s}}\left(\mathrm{CH}_{3}\right)(12)+\delta(\mathrm{C} 11 \mathrm{H} 30 \mathrm{O})(7)+v(\mathrm{O} 2 \mathrm{C})(13)$ \\
\hline 1396 & 1377 & 1354 & 1385 & 1383 & $\mathrm{R} 1[v(\mathrm{CC})(64)+v(\mathrm{OC})(13)]+\delta(\mathrm{C} 11 \mathrm{H} 30 \mathrm{O})(7)$ \\
\hline 1351 & 1333 & 1333 & 1342 & 1344 & $\mathrm{R} 2\left[\delta_{\text {in }}(\mathrm{CH})(54)+v(\mathrm{CC})(37)\right]$ \\
\hline 1335 & 1318 & 1315 & 1317 & 1317 & $\mathrm{R} 2\left[v(\mathrm{CC})(70)+\delta_{\text {in }}(\mathrm{CH})(16)\right]$ \\
\hline 1317 & 1300 & 1303 & & 1290 & $\mathrm{R} 1\left[v(\mathrm{CC})(49)+v(\mathrm{CO})(32)+\delta_{\text {in }}(\mathrm{CH})(5)\right]$ \\
\hline 1304 & 1287 & 1286 & 1283 & & $\mathrm{R} 1\left[\delta_{\text {in }}(\mathrm{CH})\right](42)+\delta(\mathrm{C} 7 \mathrm{H} 25 \mathrm{O})(17)+\delta(\mathrm{C} 11 \mathrm{HO})(16)$ \\
\hline 1280 & 1265 & 1265 & 1269 & & $v(\mathrm{CC})(45)+\mathrm{R} 1\left(\delta_{\text {trig }}\right)(11)+\delta(\mathrm{C} 7 \mathrm{HO})(8)+v(\mathrm{OC})(6)$ \\
\hline 1242 & 1228 & 1228 & 1238 & 1237 & $\mathrm{R} 2\left[v(\mathrm{CC})(18)+\delta_{\text {in }}(\mathrm{CH})(8)\right]+\mathrm{R} 1\left[v(\mathrm{C} 11 \mathrm{O})(16)+\delta_{\text {trig }}(10)\right]$ \\
\hline 1226 & 1212 & 1209 & 1209 & 1213 & $\begin{array}{l}\rho^{\prime}\left(\mathrm{CH}_{3}\right)(33)+\mathrm{R} 1\left[v(\mathrm{O} 2 \mathrm{C})(16)+\delta_{\text {in }}(\mathrm{C} 10 \mathrm{H})(12)+\rho\left(\mathrm{CH}_{3}\right)(8)+v(\right. \\
\mathrm{C} 4 \mathrm{C})(5)\end{array}$ \\
\hline 1218 & 1205 & 1192 & 1194 & 1196 & $\mathrm{R} 2\left[\delta_{\text {in }}(\mathrm{CH})(64)+v(\mathrm{CC})(7)+\rho^{\prime}\left(\mathrm{CH}_{3}\right)(5)\right]$ \\
\hline 1198 & 1185 & 1185 & & & $\mathrm{R} 1\left[\delta_{\text {in }}(\mathrm{C} 10 \mathrm{H})\right](19)+\delta(\mathrm{C} 11 \mathrm{HO})(18)+v(\mathrm{O} 1 \mathrm{C})(7)$ \\
\hline 1187 & 1174 & 1172 & & & $\delta(\mathrm{C} 7 \mathrm{HO})(30)+\mathrm{R} 1\left[\delta_{\text {in }}(\mathrm{C} 8 \mathrm{H})(17)+v(\mathrm{C} 4 \mathrm{C})(7)+v(\mathrm{O} 2 \mathrm{C})(5)\right]$ \\
\hline 1182 & 1169 & 1171 & 1161 & 1167 & $\mathrm{R} 2\left[\delta_{\text {in }}(\mathrm{CH})(74)+v(\mathrm{C} 15 \mathrm{C})(17)\right]$ \\
\hline 1170 & 1158 & 1158 & & & $\rho\left(\mathrm{CH}_{3}\right)(73)+\rho^{\prime}\left(\mathrm{CH}_{3}\right)(20)+\delta_{\mathrm{a}}\left(\mathrm{CH}_{3}\right)(5)$ \\
\hline 1169 & 1157 & 1139 & & 1166 & $\begin{array}{l}\delta(\mathrm{C} 11 \mathrm{HO})(20)+\mathrm{R} 1\left[\delta_{\text {trig }}(\mathrm{O} 1 \mathrm{C})(14)+v(\mathrm{C} 8 \mathrm{C})(19)+v(\mathrm{C} 11 \mathrm{O})(1\right. \\
4)]+\delta(\mathrm{C} 7 \mathrm{HO})(13)\end{array}$ \\
\hline 1121 & 1110 & 1120 & 1128 & 1125 & $\begin{array}{l}\mathrm{R} 1\left[v(\mathrm{C} 4 \mathrm{C})(15)+v(\mathrm{OC})(22)+v(\mathrm{O} 2 \mathrm{H})(7)+v(\mathrm{C} 7 \mathrm{C})(7)+\delta_{\text {trig }}(12\right. \\
)]+\mathrm{R} 2[v(\mathrm{C} 6 \mathrm{C} 13)(5)]\end{array}$ \\
\hline 1101 & 1091 & 1092 & 1082 & & $\mathrm{R} 2\left[v(\mathrm{CC})(48)+\delta_{\text {in }}(\mathrm{CH})(31)\right]$ \\
\hline 1052 & 1043 & 1039 & 1028 & & $\mathrm{R} 2\left[v(\mathrm{CC})(49)+\delta_{\text {in }}(\mathrm{CH})(22)\right]+\mathrm{R} 1\left[\delta_{\text {trig }}(\mathrm{OC})\right](10)$ \\
\hline 1042 & 1033 & 1011 & 1011 & 1034 & $v(\mathrm{O} 1 \mathrm{C} 17)(45)+\mathrm{R} 1\left(\delta_{\text {trig }}\right)(25)$ \\
\hline 1017 & 1009 & 1007 & & & $\mathrm{R} 1\left[(\mathrm{O} 1 \mathrm{C})\left(\delta_{\mathrm{trig}}\right)(35)+v(\mathrm{OC})(13)\right]+\mathrm{R} 2[v(\mathrm{CC})(44)]$ \\
\hline 1007 & 999 & 1006 & 1001 & 1001 & $\mathrm{R} 2\left[\delta_{\text {oop }}(\mathrm{CH})\right](78)+\mathrm{R} 1(\mathrm{puck})(16)$ \\
\hline 993 & 985 & 991 & 977 & 966 & $\mathrm{R} 2\left[\delta_{\mathrm{oop}}(\mathrm{CH})\right](90)+\mathrm{R} 1\left[\left(\tau_{\mathrm{a}}^{\prime}\right)(8)\right.$ \\
\hline 952 & 945 & 949 & 933 & 934 & $\mathrm{R} 2\left[\delta_{\text {oop }}(\mathrm{CH})(78)+\delta_{\text {oop }}(\mathrm{CC})(5)\right]+\mathrm{R} 1\left[\tau_{\mathrm{a}}(6)+\operatorname{puck}(5)\right]$ \\
\hline 939 & 933 & 927 & 918 & & $\begin{array}{l}\delta(\mathrm{C} 5 \mathrm{OC})(15)+\mathrm{R} 1\left[v(\mathrm{OC})(21)+\delta_{\text {oop }}(\mathrm{C} 8 \mathrm{H})(5)\right]+\mathrm{R} 2[v(\mathrm{CC} 13)( \\
6)]\end{array}$ \\
\hline 906 & 900 & 891 & 885 & 906 & $\mathrm{R} 1\left[\delta_{\text {oop }}(\mathrm{CH})(74)+\tau_{\mathrm{a}}(8)\right]$ \\
\hline
\end{tabular}




\begin{tabular}{|c|c|c|c|c|c|}
\hline 859 & 854 & 864 & 854 & 859 & $\mathrm{R} 2\left[\delta_{\text {oop }}(\mathrm{CH})\right](99)$ \\
\hline 839 & 835 & 863 & 842 & 839 & $\mathrm{R} 1\left[\delta_{\text {oop }}(\mathrm{C} 10 \mathrm{H})(47)+\operatorname{puck}(25)+\delta_{\text {oop }}(\mathrm{CO})(13)\right]$ \\
\hline 815 & 810 & 821 & 825 & 815 & $\mathrm{R} 1\left[\delta_{\text {oop }}(\mathrm{CC})(27)+\delta_{\text {oop }}(\mathrm{CH})(24)+v(\mathrm{CO})(5)+\delta_{\text {trig }}(5)\right]$ \\
\hline 800 & 796 & 791 & 802 & 800 & $\begin{array}{l}\mathrm{R} 1\left[\text { puck }(13)+v(\mathrm{C} 11 \mathrm{O})(12)+\delta_{\text {oop }}(\mathrm{CH})(8)+v(\mathrm{C} 9 \mathrm{C})(8)+\delta_{\text {trig }}(6\right. \\
)]+\mathrm{R} 2\left[\delta_{\text {oop }}(\mathrm{CC})(15)\right]\end{array}$ \\
\hline 750 & 747 & 746 & 759 & 750 & $\begin{array}{l}\mathrm{R} 1\left[\text { puck }(13)+\delta_{\text {oop }}(\mathrm{CC})(14)+\delta_{\text {oop }}(\mathrm{C} 7 \mathrm{O})(8)+v(\mathrm{C} 9 \mathrm{C})(5)\right]+\mathrm{R} 2[ \\
\left.\delta_{\text {oop }}(\mathrm{CH})\right](14)\end{array}$ \\
\hline 736 & 733 & 735 & 736 & 736 & $\begin{array}{l}\mathrm{R} 1\left[\mathrm{puck}(13)+\delta_{\mathrm{a}}(\mathrm{O} 1 \mathrm{C})(13)+\delta_{\text {oop }}(\mathrm{C} 4 \mathrm{C})(6)+\delta_{\text {oop }}(\mathrm{C} 7 \mathrm{O})(5)+v(\right. \\
\mathrm{CC})(10)]\end{array}$ \\
\hline 711 & 708 & 725 & & 711 & $\mathrm{R} 1\left[\delta_{\mathrm{oop}}(\mathrm{CO})(48)+\operatorname{puck}(20)+\tau_{\mathrm{a}}{ }^{(}(12)\right]+\delta(\mathrm{C} 9 \mathrm{C} 17 \mathrm{O} 1)(6)$ \\
\hline 705 & 703 & 709 & 700 & 705 & $\mathrm{R} 1\left[\operatorname{puck}(48)+\delta_{\text {oop }}(\mathrm{CH})(34)+\delta_{\text {oop }}(\mathrm{CC})(5)\right]$ \\
\hline 693 & 691 & 693 & 686 & 693 & $\mathrm{R} 1\left[\operatorname{puck}(29)+(\mathrm{O} 1 \mathrm{C})\left(\delta_{\mathrm{a}}\right)(18)+\delta_{\text {oop }}(\mathrm{C} 7 \mathrm{O})(11)\right]$ \\
\hline 688 & 686 & 676 & 665 & 688 & $\mathrm{R} 1\left[\operatorname{puck}(39)+\delta_{\text {oop }}(\mathrm{C} 7 \mathrm{O})(9)+\delta_{\text {in }}(\mathrm{C} 5 \mathrm{C})(5)\right]$ \\
\hline 632 & 631 & 636 & 633 & 632 & $\mathrm{R} 1\left[\delta_{\mathrm{a}}(\mathrm{O} 1 \mathrm{C})(80)+\delta_{\mathrm{oop}}(\mathrm{O} 29 \mathrm{H})(13)\right]$ \\
\hline 614 & 613 & 628 & 592 & 614 & $\mathrm{R} 1\left[\delta_{\text {in }}(\mathrm{C} 11 \mathrm{O})(31)+\delta_{\text {oop }}(\mathrm{CO})(14)+\delta_{\text {oop }}(\mathrm{CC})(5)+\delta_{\text {in }}(\mathrm{C} 7 \mathrm{O})(5)\right]$ \\
\hline 592 & 591 & 614 & & 592 & $\begin{array}{l}\mathrm{R} 1\left[\delta_{\text {oop }}(\mathrm{C} 7 \mathrm{O})(19)+\operatorname{puck}(14)+\delta(\mathrm{C} 5 \mathrm{OC})(12)+\delta_{\mathrm{a}}(\mathrm{OC})(15)+\delta_{\mathrm{i}}\right. \\
\mathrm{n}(\mathrm{CO})(6)]\end{array}$ \\
\hline 538 & 537 & 530 & 540 & 538 & $\begin{array}{l}\mathrm{R} 1\left[\tau_{\mathrm{a}}(15)+\delta_{\text {in }}(\mathrm{C} 5 \mathrm{C})(13)+\delta_{\mathrm{a}}(\mathrm{O} 1 \mathrm{C})(8)+\delta_{\text {oop }}(\mathrm{C} 7 \mathrm{O})(7)+\delta_{\text {in }}(\mathrm{C} 7\right. \\
\mathrm{O})(5)]+\mathrm{R} 2\left[\delta_{\text {oop }}(\mathrm{C} 6 \mathrm{C} 5)\right](11)\end{array}$ \\
\hline 484 & 484 & 490 & 513 & 484 & $\begin{array}{l}\mathrm{R} 1\left[\tau_{\mathrm{a}}(26)+\delta_{\text {oop }}(\mathrm{C} 11 \mathrm{O})(21)+\delta^{\prime}{ }_{\mathrm{a}}(\mathrm{O} 1 \mathrm{C})(11)+\delta_{\mathrm{a}}(\mathrm{O} 1 \mathrm{C})(7)+\delta_{\text {oop }}\right. \\
(\mathrm{C} 9 \mathrm{O} 1)(5)+\delta(\mathrm{C} 9 \mathrm{CO})(5)]\end{array}$ \\
\hline 461 & 461 & 477 & 476 & 461 & $\mathrm{R} 1\left[\tau_{\mathrm{a}}(33)+\delta_{\text {oop }}(\mathrm{CO})(29)+\delta^{\prime}{ }_{\mathrm{a}}(\mathrm{O} 1 \mathrm{C} 9)(9)\right]$ \\
\hline 458 & 458 & 426 & 459 & 458 & $\begin{array}{l}\mathrm{R} 1\left[\tau_{\mathrm{a}}(\mathrm{OC})(29)+\delta_{\text {oop }}(\mathrm{CC})(8)+\delta_{\text {oop }}(\mathrm{CO})(8)+\delta_{\mathrm{a}}(\mathrm{OC})(7)\right]+\mathrm{R} 2[\mathrm{v} \\
\left.(\mathrm{CC})(5)+\delta_{\text {oop }}(\mathrm{CC})(10)\right]\end{array}$ \\
\hline 416 & 416 & 418 & & 416 & $\begin{array}{l}\mathrm{R} 1\left[\tau_{\mathrm{a}}(32)+\tau_{\mathrm{a}}(11)+\delta_{\text {oop }}(\mathrm{CO})(5)+\delta_{\mathrm{a}}{ }_{\mathrm{a}}(5)+\delta_{\text {oop }}(\mathrm{CC})(5)+\mathrm{R} 2\left[\delta_{\mathrm{oo}}\right.\right. \\
(\mathrm{CC})](10)\end{array}$ \\
\hline 414 & 414 & 411 & 410 & 414 & $\mathrm{R} 1\left[\tau_{\mathrm{a}}^{\prime}(76)+\delta_{\text {oop }}(\mathrm{C} 14 \mathrm{H})(5)\right]$ \\
\hline 401 & 401 & 383 & & 401 & $\mathrm{R} 2\left[\delta_{\text {in }}(\mathrm{C} 11 \mathrm{O})(17)+\delta^{\prime}{ }_{\mathrm{a}}(\mathrm{O} 1 \mathrm{C})(15)\right]+\delta(\mathrm{C} 5 \mathrm{O} 3 \mathrm{C} 4)(17)$ \\
\hline 385 & 385 & 374 & & 385 & $\delta(\mathrm{C} 9 \mathrm{C} 17 \mathrm{O})(23)+\mathrm{R} 1\left[\delta_{\text {in }}(\mathrm{C} 7 \mathrm{O})(28)+\tau_{\mathrm{a}}(8)+\delta_{\text {oop }}(\mathrm{C} 9 \mathrm{O})(8)\right]$ \\
\hline 337 & 337 & 350 & - & 337 & $\begin{array}{l}\mathrm{R} 1\left[\delta_{\text {in }}(\mathrm{CO})(37)\right]+\delta(\mathrm{C} 5 \mathrm{O} 3 \mathrm{C})(11)+\delta_{\text {oop }}(\mathrm{C} 11 \mathrm{O})(8)+\delta_{\text {in }}(\mathrm{C} 6 \mathrm{C})( \\
5)\end{array}$ \\
\hline 319 & 320 & 335 & - & 319 & $\mathrm{R} 1\left[\tau(\mathrm{O} 2 \mathrm{C})(71)+\delta_{\text {in }}(\mathrm{C} 9 \mathrm{O})(7)\right]$ \\
\hline 281 & 282 & 287 & - & 281 & $\begin{array}{l}\mathrm{R} 1\left[\delta_{\text {in }}(\mathrm{C} 9 \mathrm{O})(29)+\tau(\mathrm{C} 11 \mathrm{O})(20)+\tau(\mathrm{O} 2 \mathrm{C})(14)+\delta_{\text {oop }}(\mathrm{C} 7 \mathrm{O})(5)\right. \\
+\tau(\mathrm{O} 1 \mathrm{C})(5)]\end{array}$ \\
\hline 250 & 250 & 280 & - & 250 & $\mathrm{R} 1\left[\tau(\mathrm{C} 11 \mathrm{O})(63)+\delta_{\text {in }}(\mathrm{C} 9 \mathrm{O})(10)\right]$ \\
\hline 248 & 249 & 247 & - & 248 & $\mathrm{R} 2\left[\delta_{\text {in }}(\mathrm{C} 6 \mathrm{C})(28)\right]+\mathrm{R} 1\left[v(\mathrm{C} 4 \mathrm{C})(15)+\delta^{\prime}{ }_{\mathrm{a}}(11)+\operatorname{puck}(5)\right]$ \\
\hline 217 & 217 & 233 & - & 217 & $\begin{array}{l}\delta_{\text {in }}(\mathrm{C} 4 \mathrm{C} 5)(14)+\mathrm{R} 1\left[\tau(\mathrm{O} 1 \mathrm{C})(13)+\delta_{\text {oop }}(\mathrm{C} 10 \mathrm{H})(8)+\tau(\mathrm{O} 1 \mathrm{C})(8)+\right. \\
\left.\delta_{\text {oop }}(\mathrm{C} 9 \mathrm{O})(7)\right]\end{array}$ \\
\hline 211 & 212 & 204 & - & 211 & $\begin{array}{l}\mathrm{R} 1\left[\tau_{\mathrm{a}}(19)+\delta_{\text {oop }}(\mathrm{CH})(8)+\delta(\mathrm{C} 9 \mathrm{CO})(7)+\delta_{\text {oop }}(\mathrm{CC})(6)\right]+\mathrm{R} 2\left[\delta_{\text {in }}(\right. \\
\mathrm{CC})](25)\end{array}$ \\
\hline 191 & 192 & 180 & - & 191 & $\mathrm{R} 1\left[\delta_{\text {in }}(\mathrm{C} 4 \mathrm{C})(26)+\tau_{\mathrm{a}}(16)+\delta_{\text {oop }}(\mathrm{C} 6 \mathrm{C})(15)+\tau(\mathrm{C} 4 \mathrm{C})(5)\right]$ \\
\hline 176 & 177 & 158 & - & 176 & $\begin{array}{l}\mathrm{R} 1\left[\tau_{\mathrm{a}}(20)+\tau(\mathrm{CC})(23)+\delta_{\text {oop }}(\mathrm{C} 4 \mathrm{C} 5)(13)+\delta_{\text {in }}(\mathrm{C} 4 \mathrm{C})(10)+\delta_{\text {oop }}(\right. \\
\mathrm{C} 5 \mathrm{C})(10)]\end{array}$ \\
\hline 147 & 148 & 140 & - & 147 & $\mathrm{R} 1\left[\tau(\mathrm{O} 1 \mathrm{C})(42)+\delta_{\text {oop }}(\mathrm{C} 9 \mathrm{O})(12)+\delta(\mathrm{C} 9 \mathrm{CO})(8)\right]$ \\
\hline 113 & 113 & 99 & - & 113 & $\begin{array}{l}\mathrm{R} 1\left[\tau^{\prime}{ }_{\mathrm{a}}(10)+\tau(\mathrm{C} 4 \mathrm{C})(9)+\delta_{\text {in }}(\mathrm{C} 4 \mathrm{C})(5)+\mathrm{R} 2\left[\tau(\mathrm{C} 5 \mathrm{C})(23)+\delta_{\text {oop }}(\mathrm{C}\right.\right. \\
\left.\mathrm{C})(16)+\delta_{\text {in }}(\mathrm{CC})(10)\right]\end{array}$ \\
\hline 88 & 88 & 62 & - & 87 & $\mathrm{R} 1\left[\tau_{\mathrm{a}}^{\prime}(39)+\tau(\mathrm{C} 4 \mathrm{C})(33)+\delta_{\text {oop }}(\mathrm{C} 4 \mathrm{C} 5)(8)\right]$ \\
\hline 48 & 48 & 58 & - & 48 & $\mathrm{R} 1\left[\tau(\mathrm{O} 1 \mathrm{C})(6)+\delta_{\mathrm{in}}(\mathrm{C} 9 \mathrm{O})(9)\right]+\delta(\mathrm{C} 9 \mathrm{CO})(8)$ \\
\hline 43 & 43 & 46 & - & 43 & $\mathrm{R} 1\left[\tau(\mathrm{O} 1 \mathrm{C})(56)+\tau(\mathrm{C} 5 \mathrm{C})(18)+\delta_{\text {in }}(\mathrm{C} 9 \mathrm{O} 1)(7)\right]+\delta(\mathrm{C} 9 \mathrm{C} 17 \mathrm{O})(7)$ \\
\hline 30 & 30 & 28 & - & 29 & $\mathrm{R} 1[\tau(\mathrm{CC})(53)+\tau(\mathrm{O} 1 \mathrm{C})(21)]$ \\
\hline
\end{tabular}


Table 2

Second order perturbation theory analysis of Fock matrix in NBO basis for CRN I.

\begin{tabular}{|c|c|c|c|c|c|c|}
\hline Donor NBO (i) & ED(i)/e & Acceptor NBO(j) & $E D(j) / e$ & $\mathrm{E}(2)^{\mathrm{a}} \mathrm{kcal} / \mathrm{mol}$ & $E(j)-E(i)^{b}$ & $F(i, j)^{c}$ \\
\hline \multirow[t]{3}{*}{$\pi(\mathrm{C} 4-\mathrm{C} 7)$} & 1.63718 & $\pi^{*}(\mathrm{O} 3-\mathrm{C} 5)$ & 0.18625 & 13.80 & 0.27 & 0.057 \\
\hline & 1.63718 & $\pi^{*}(\mathrm{C} 8-\mathrm{C} 11)$ & 0.36169 & 22.61 & 0.28 & 0.071 \\
\hline & 1.63718 & $\pi^{*}(\mathrm{C} 9-\mathrm{C} 10)$ & 0.01880 & 17.26 & 0.27 & 0.062 \\
\hline \multirow[t]{3}{*}{$\pi(\mathrm{C} 6-\mathrm{C} 12)$} & 1.62449 & $\pi^{*}(\mathrm{O} 3-\mathrm{C} 5)$ & 0.18625 & 18.04 & 0.26 & 0.064 \\
\hline & 1.62449 & $\pi^{*}(\mathrm{C} 13-\mathrm{C} 15)$ & 0.29322 & 20.22 & 0.28 & 0.069 \\
\hline & 1.62449 & $\pi^{*}(\mathrm{C} 14-\mathrm{C} 16)$ & 0.32959 & 18.95 & 0.27 & 0.065 \\
\hline \multirow[t]{2}{*}{$\pi(\mathrm{C} 8-\mathrm{C} 11)$} & 1.69985 & $\pi^{*}(\mathrm{C} 4-\mathrm{C} 7)$ & 0.44097 & 15.32 & 0.29 & 0.062 \\
\hline & 1.69985 & $\pi^{*}(\mathrm{C} 9-\mathrm{C} 10)$ & 0.40014 & 21.52 & 0.28 & 0.071 \\
\hline \multirow[t]{2}{*}{$\pi(\mathrm{C} 9-\mathrm{C} 10)$} & 1.68114 & $\pi^{*}(\mathrm{C} 4-\mathrm{C} 7)$ & 0.44097 & 23.41 & 0.29 & 0.076 \\
\hline & 1.68114 & $\pi^{*}(\mathrm{C} 8-\mathrm{C} 11)$ & 0.36169 & 16.01 & 0.29 & 0.061 \\
\hline \multirow[t]{2}{*}{$\pi(\mathrm{C} 13-\mathrm{C} 15)$} & 1.65315 & $\pi^{*}(\mathrm{C} 6-\mathrm{C} 12)$ & 0.36314 & 18.63 & 0.28 & 0.065 \\
\hline & 1.65315 & $\pi^{*}(\mathrm{C} 14-\mathrm{C} 16)$ & 0.32959 & 21.99 & 0.28 & 0.070 \\
\hline \multirow[t]{2}{*}{$\pi(\mathrm{C} 14-\mathrm{C} 16)$} & 1.65261 & $\pi^{*}(\mathrm{C} 6-\mathrm{C} 12)$ & 0.36314 & 21.86 & 0.28 & 0.071 \\
\hline & 1.65261 & $\pi^{*}(\mathrm{C} 13-\mathrm{C} 15)$ & 0.29322 & 17.60 & 0.29 & 0.064 \\
\hline LP ( 2)O1 & 1.85674 & $\pi^{*}(\mathrm{C} 9-\mathrm{C} 10)$ & 0.40014 & 23.07 & 0.34 & 0.084 \\
\hline $\mathrm{LP}(2) \mathrm{O} 2$ & 1.97793 & $\pi^{*}(\mathrm{C} 4-\mathrm{C} 7)$ & 0.44097 & 24.87 & 0.35 & 0.091 \\
\hline \multirow[t]{2}{*}{ LP (2)O3 } & 1.90144 & $\pi^{*}(\mathrm{C} 4-\mathrm{C} 5)$ & 0.05824 & 16.41 & 0.69 & 0.096 \\
\hline & 1.90144 & $\pi^{*}(\mathrm{C} 5-\mathrm{C} 6)$ & 0.05750 & 15.56 & 0.70 & 0.094 \\
\hline LP (2)O29 & 1.90483 & $\pi^{*}(\mathrm{C} 8-\mathrm{C} 11)$ & 0.36169 & 21.51 & 0.35 & 0.083 \\
\hline$\pi(\mathrm{O} 3-\mathrm{C} 5)$ & 1.96690 & $\pi^{*}(\mathrm{C} 6-\mathrm{C} 12)$ & 0.36314 & 58.53 & 0.02 & 0.065 \\
\hline
\end{tabular}

${ }^{a} \mathrm{E}(2)$ means the energy of hyperconjugative interaction (stabilization energy).

${ }^{b}$ Energy difference between donor (i) and acceptor (j) NBO orbitals.

${ }^{c} \mathrm{~F}(\mathrm{i}, \mathrm{j})$ is the Fock matrix element between $\mathrm{i}$ and $\mathrm{j}$ NBO orbitals. 
Table 3

Selected Lewis orbitals (occupied bond orbital) with percentage $\mathrm{ED}$ over bonded atoms $\left(\mathrm{ED}_{\mathrm{X}}, \mathrm{ED}_{\mathrm{Y}}\right.$ in $\%)$, hybrid NBOs with s and $\mathrm{p}$ character in \% for CRN I.

\begin{tabular}{|c|c|c|c|c|}
\hline $\begin{array}{c}\text { Bond }(X-Y) \\
\left(E_{X-Y}\right)\end{array}$ & $\begin{array}{l}E_{X}(\%) \\
\operatorname{ED}_{Y}(\%)\end{array}$ & Hybrid NBOs & s (\%) & p (\%) \\
\hline$\sigma(\mathrm{O} 1-\mathrm{C} 9)$ & $66.93 \%$ & $0.8181\left(\mathrm{sp}^{2.06}\right) \mathrm{o}^{+}$ & $32.66 \%$ & $67.27 \%$ \\
\hline (1.99158) & $33.07 \%$ & $0.5750\left(\mathrm{sp}^{2.96}\right) \mathrm{c}^{+}$ & $25.21 \%$ & $74.58 \%$ \\
\hline$\sigma(\mathrm{O} 1-\mathrm{C} 17)$ & $69.37 \%$ & $0.8329\left(\mathrm{sp}^{2.67}\right) \mathrm{o}^{+}$ & $27.26 \%$ & $72.69 \%$ \\
\hline (1.98949) & $30.63 \%$ & $0.5534\left(\mathrm{sp}^{3.85}\right) \mathrm{c}^{+}$ & $20.57 \%$ & $79.14 \%$ \\
\hline$\sigma(\mathrm{O} 2-\mathrm{C} 7)$ & $66.81 \%$ & $0.8174\left(\mathrm{sp}^{1.99}\right) \mathrm{o}^{+}$ & $33.48 \%$ & $66.45 \%$ \\
\hline (1.99356) & $33.19 \%$ & $0.5761\left(\mathrm{sp}^{3.14}\right) \mathrm{c}^{+}$ & $24.09 \%$ & $75.70 \%$ \\
\hline$\sigma(\mathrm{O} 29-\mathrm{C} 11)$ & $66.61 \%$ & $0.8162\left(\mathrm{sp}^{2.06}\right) \mathrm{o}^{+}$ & $32.62 \%$ & $67.31 \%$ \\
\hline$(1.99356)$ & $33.39 \%$ & $0.5778\left(\mathrm{sp}^{3.11}\right) \mathrm{c}^{+}$ & $24.27 \%$ & $75.52 \%$ \\
\hline$\sigma(\mathrm{O} 3-\mathrm{C} 5)$ & $64.74 \%$ & $0.8046\left(\mathrm{sp}^{1.59}\right) \mathrm{o}+$ & $38.63 \%$ & $61.27 \%$ \\
\hline (1.99234) & $35.26 \%$ & $0.5938\left(\mathrm{sp}^{2.39}\right) \mathrm{c}^{+}$ & $29.45 \%$ & $70.36 \%$ \\
\hline$\sigma(\mathrm{O} 2-\mathrm{H} 25)$ & $73.99 \%$ & $0.8602\left(\mathrm{sp}^{3.80}\right) \mathrm{o}^{+}$ & $20.80 \%$ & $79.11 \%$ \\
\hline$(1.98760)$ & $26.01 \%$ & $0.5100\left(\mathrm{sp}^{0.00}\right) \mathrm{H}^{+}$ & $99.88 \%$ & $0.12 \%$ \\
\hline$\sigma(\mathrm{O} 29-\mathrm{H} 30)$ & $74.16 \%$ & $0.8612\left(\mathrm{sp}^{3.74}\right) \mathrm{o}^{+}$ & $21.09 \%$ & $78.82 \%$ \\
\hline$(1.98794)$ & $35.26 \%$ & $0.5938\left(\mathrm{sp}^{2.39}\right) \mathrm{H}^{+}$ & $99.88 \%$ & $0.12 \%$ \\
\hline
\end{tabular}


Table 4 Electronic transitions, absorption wavelength $\lambda_{\max }(\mathrm{nm})$, excitation energy (eV) and oscillator strengths (f) of CRN I and CRN II.

\begin{tabular}{|c|c|c|c|c|c|c|c|c|c|c|c|c|}
\hline \multirow[t]{2}{*}{$\begin{array}{l}\text { Excited } \\
\text { state }\end{array}$} & \multirow[t]{2}{*}{ Experimental } & \multirow[t]{2}{*}{ Conformers } & \multicolumn{5}{|c|}{$\begin{array}{l}\text { Calculated } \\
\text { Gas phase }\end{array}$} & \multicolumn{5}{|c|}{ DMSO } \\
\hline & & & $\begin{array}{l}\lambda \max \\
(\mathrm{nm})\end{array}$ & $\mathrm{E}(\mathrm{eV})$ & $\begin{array}{l}\text { Oscillator } \\
\text { strength } \\
\text { (f) }\end{array}$ & $\begin{array}{l}\text { Excitation } \\
\text { transition }\end{array}$ & $\begin{array}{l}\text { Transition } \\
\text { type/ } \\
\text { assignment }\end{array}$ & $\begin{array}{l}\lambda \max \\
(\mathrm{nm})\end{array}$ & $\begin{array}{l}\text { Oscillator } \\
\text { strength } \\
\text { (f) }\end{array}$ & $\mathrm{E}(\mathrm{eV})$ & $\begin{array}{c}\text { Excitation } \\
\text { transition }\end{array}$ & $\begin{array}{l}\text { Transition } \\
\text { type/ } \\
\text { assignment }\end{array}$ \\
\hline \multirow[t]{2}{*}{1.} & 373 & CRN I & 355 & 3.4920 & 0.0686 & $\mathrm{H} \rightarrow \mathrm{L}$ & $\pi \rightarrow \pi^{*}$ & 379 & 0.0969 & 3.269 & $\mathrm{H} \rightarrow \mathrm{L}$ & $\sigma \rightarrow \sigma^{*}$ \\
\hline & & CRN II & 376 & 3.2935 & 0.0651 & $\mathrm{H} \rightarrow \mathrm{L}$ & $\sigma \rightarrow \sigma^{*}$ & 376 & 0.0951 & 3.296 & $\mathrm{H} \rightarrow \mathrm{L}$ & $\sigma \rightarrow \sigma^{*}$ \\
\hline
\end{tabular}


Table 5

Calculated local reactivity properties of the selected atoms using Hirshfeld [B3LYP/6-311++G(d,p)] derived charges.

\begin{tabular}{cccccccccccc}
\hline \multicolumn{1}{c}{ CRN I } \\
\hline Atom & $\mathbf{f}_{\mathbf{k}}{ }^{+}$ & Atom & $\mathbf{f}_{\mathbf{K}}^{-}$ & Atom & $\mathbf{f}_{\mathbf{K}}{ }^{\mathbf{0}}$ & Atom & $\mathbf{f}_{\mathbf{k}}{ }^{+}$ & Atom & $\mathbf{f}_{\mathbf{K}}^{-}$ & Atom $^{-} \mathbf{f}_{\mathbf{K}}{ }^{\mathbf{0}}$ \\
\hline $2 \mathbf{O}$ & 0.09385 & $3 \mathrm{O}$ & 0.11990 & $5 \mathrm{C}$ & 0.09578 & $2 \mathrm{O}$ & 0.08044 & $3 \mathrm{O}$ & 0.12622 & $5 \mathrm{C}$ & 0.10012 \\
4C & 0.07259 & $5 \mathrm{C}$ & 0.10285 & $7 \mathrm{C}$ & 0.09760 & $4 \mathrm{C}$ & 0.06687 & $5 \mathrm{C}$ & 0.10946 & $7 \mathrm{C}$ & 0.09228 \\
8C & 0.04873 & $9 \mathrm{C}$ & 0.04933 & $9 \mathrm{C}$ & 0.07226 & $7 \mathrm{C}$ & 0.06964 & $9 \mathrm{C}$ & 0.04574 & $9 \mathrm{C}$ & 0.06368 \\
$9 \mathrm{C}$ & 0.04967 & $13 \mathrm{C}$ & 0.04099 & $11 \mathrm{C}$ & 0.08280 & $9 \mathrm{C}$ & 0.05488 & $13 \mathrm{C}$ & 0.0450 & $11 \mathrm{C}$ & 0.08003 \\
$11 \mathrm{C}$ & 0.08950 & $15 \mathrm{C}$ & 0.04139 & $18 \mathrm{H}$ & 0.05080 & $11 \mathrm{C}$ & 0.08299 & $16 \mathrm{C}$ & 0.07526 & $18 \mathrm{H}$ & 0.06332 \\
$29 \mathrm{O}$ & 0.09567 & $16 \mathrm{C}$ & 0.07288 & $20 \mathrm{H}$ & 0.05928 & $29 \mathrm{O}$ & 0.09979 & $24 \mathrm{H}$ & 0.04035 & $19 \mathrm{H}$ & 0.04103 \\
\hline
\end{tabular}




\section{Table 6}

Calculated $\varepsilon_{\mathrm{HOMO}}, \varepsilon_{\mathrm{LUMO}}$, energy band gap $\left(\varepsilon_{\mathrm{H}}-\varepsilon_{\mathrm{L}}\right)$, chemical potential $(\mu)$, electronegativity $(\chi)$, global hardness $(\eta)$, global softness $(S)$ and global electrophilicity index $(\omega)$ at $298.15 \mathrm{~K}$ for conformer I and conformer II of CRN.

\begin{tabular}{cccccccccc}
\hline Molecule & $\boldsymbol{\varepsilon}_{\mathbf{H}}$ & $\boldsymbol{\varepsilon}_{\mathbf{L}}$ & $\boldsymbol{\varepsilon}_{\mathbf{H}}-\boldsymbol{\varepsilon}_{\mathbf{L}}$ & $\boldsymbol{\chi}$ & $\boldsymbol{\mu}$ & $\boldsymbol{\eta}$ & $\boldsymbol{S}$ & $\boldsymbol{\omega}$ & $\Delta \boldsymbol{N}_{\max }$ \\
\hline CRN I & -6.0714 & -2.1997 & 3.8717 & 4.1355 & -4.1355 & 1.9358 & 0.2583 & 4.4174 & 2.1363 \\
CRN II & -5.8875 & -1.7844 & 4.1031 & 3.8359 & -3.8359 & 2.0515 & 0.2437 & 3.5862 & 1.8698 \\
\hline
\end{tabular}

